Article

\title{
The Impact of Typhoon Intensity on Wave Height and Storm Surge in the Northern East China Sea: A Comparative Case Study of Typhoon Muifa and Typhoon Lekima
}

\author{
Junyan Wang 1,2,3,4, Dongxue Mo ${ }^{1,2,3,4, *}$, Yijun Hou ${ }^{1,2,3,4}$, Shuiqing Li 1,2,3,4 ${ }^{\text {, Jian Li }}{ }^{5}$, Mei Du 6 (D) \\ and Baoshu Yin 1,2,3,4,*
}

check for updates

Citation: Wang, J.; Mo, D.; Hou, Y.; Li, S.; Li, J.; Du, M.; Yin, B. The Impact of Typhoon Intensity on Wave Height and Storm Surge in the Northern East China Sea: A Comparative Case Study of Typhoon Muifa and Typhoon Lekima. J. Mar. Sci. Eng. 2022, 10, 192. https:// doi.org/10.3390/jmse10020192

Academic Editor: Han Soo Lee

Received: 18 January 2022

Accepted: 28 January 2022

Published: 31 January 2022

Publisher's Note: MDPI stays neutral with regard to jurisdictional claims in published maps and institutional affiliations.

Copyright: (C) 2022 by the authors. Licensee MDPI, Basel, Switzerland. This article is an open access article distributed under the terms and conditions of the Creative Commons Attribution (CC BY) license (https:// creativecommons.org/licenses/by/ $4.0 /)$.
1 Key Laboratory of Ocean Circulation and Waves, Institute of Oceanology, Chinese Academy of Sciences, Nanhai Road 7, Qingdao 266071, China; wangjunyan@qdio.ac.cn (J.W.); yjhou@qdio.ac.cn (Y.H.); lishuiqing@qdio.ac.cn (S.L.)

2 University of Chinese Academy of Sciences, Yuquan Road 19A, Beijing 100049, China

3 Laboratory for Ocean Dynamics and Climate, Pilot National Laboratory for Marine Science and Technology (Qingdao), Wenhai Road 1, Qingdao 266237, China

4 Center for Ocean Mega-Science, Chinese Academy of Sciences, Nanhai Road 7, Qingdao 266071, China

5 North China Sea Marine Forecasting Center of State Oceanic Administration, Yunling Road 27, Qingdao 266061, China; lijian_bhybzx@ncs.mnr.gov.cn

6 Department of Mathematical and Physics, Shijiazhuang Tiedao University, 17 Northeast Second Inner Ring, Shijiazhuang 050043, China; dumei_ocean@163.com

* Correspondence: dongxuemo@qdio.ac.cn (D.M.); bsyin@qdio.ac.cn (B.Y.); Tel.: +86-0532-8289-8873 (D.M. \& B.Y.)

\begin{abstract}
A comparative study was conducted on typhoon intensity factors affecting the marine environment using two representative cases: Typhoon Lekima, which made landfall at Shandong Peninsula, the Northern East China Sea, and Typhoon Muifa, which did not. Using the ADCIRC and SWAN models, we developed a coupled numerical model and applied it to simulate the storm surge and destructive waves caused by typhoons. Three typhoon parameters-maximum wind speed, radius of maximum wind speed, and translation speed-were investigated through sensitivity experiments. The storm surge during the typhoon that made landfall showed a positive correlation with the distance of the typhoon's center. The maximum significant wave height and storm surge had near-linear growth with a maximum wind speed but decreased with the growth rate of the radius of maximum wind. A rapid typhoon translation speed from $47 \mathrm{~km} / \mathrm{h}$ to $60 \mathrm{~km} / \mathrm{h}$ could cause a storm surge resonance phenomenon at the northern coast of the East China Sea.
\end{abstract}

Keywords: ADCIRC-SWAN coupled model; typhoon intensity; storm surge; significant wave height; the Northern East China Sea

\section{Introduction}

Typhoons (also known as hurricanes in the Atlantic and northeast Pacific oceans) are among the most extreme meteorological systems in the world [1]. A storm surge is an unusual fluctuation of sea level that is often caused by strong meteorological processes [2-4]. Typhoon-induced storm surges are extremely destructive and can cause serious damage, especially in heavily developed and densely populated areas [5]. One of the most commonly used tools for numerically modeling storm surges and waves is hydrodynamic modeling, which has been used in New York City (USA) [6,7], the Gulf of Mexico (USA) [8,9], and the Bay of Bengal (Bangladesh) [10-12]. Along the southeast and northeast coast of China, a hydrodynamic model has also been used in Pearl River Estuary [13-15], Zhejiang Province [16,17], Shanghai [18,19], Taiwan [20-25], and Tianjin [26].

The Northern East China Sea, which includes the Bohai Sea and the Northern Yellow Sea, is extremely vulnerable to typhoons [26-28]. Between 1960 and 1997, 65 typhoons occurred in the Yellow Sea and Bohai Sea, including 22 typhoons that caused storm surges 
of more than $0.5 \mathrm{~m}$ at the Qingdao tidal gauges [29]. Between 2000 and 2020, 12 typhoons affected the Northern East China Sea (Figure 1), some of which made landfall at Shandong Peninsula and others that did not $[30,31]$.
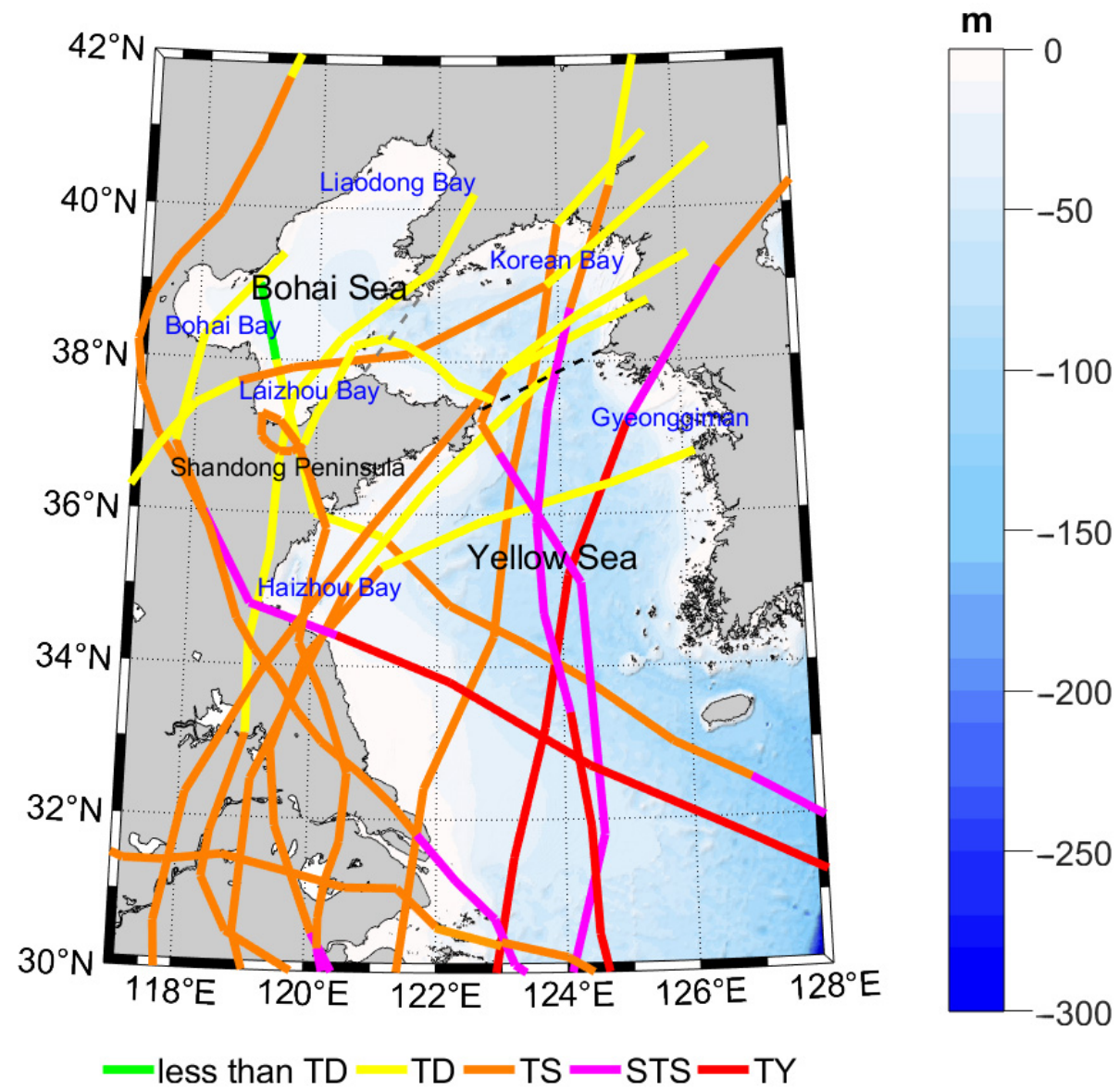

Figure 1. Historical paths of typhoons that have passed through the Northern East China Sea from 2000 to 2019. Different colors represent different typhoon intensities, which were classified by the China Meteorological Administration, including TD (Tropical Depression), TS (Tropical Storm), STS (Strong Tropical Storm), and TY (Typhoon). Bathymetry is shown in blue in the background. The gray dash line is the dividing line between the Bohai Sea and the Yellow Sea. The black dash line is dividing line between the Northern East China Sea and the South Yellow Sea. Data of typhoon intensities are from CMA Tropical Cyclone Data Center [32].

Typhoon Muifa (2011) and Typhoon Lekima (2019) were super typhoons that caused a substantial amount of damage in the Northern East China Sea [33]. Typhoon Muifa (2011) affected 3.65 million people, including 1.35 million people that were relocated. More than 600 houses collapsed, and more than 4800 houses were damaged, resulting in direct losses of almost 3.13 billion yuan. Typhoon Lekima (2019) passed over Shandong Peninsula and caused 33 million yuan in direct losses just in Wushan Town. In total, more than 14 million people were affected, and more than 2 million people were relocated. Typhoon Lekima caused the collapse of more than 15 thousand houses, as well as 57 deaths and 14 people going missing.

Typhoon Lekima was the strongest typhoon to make landfall on Shandong Peninsula, and Typhoon Muifa was the strongest typhoon to pass by Shandong Peninsula but not make landfall there. As shown in Table 1, 12 typhoons passed through the Northern East China Sea during 2000-2019. Nine of these made landfall on Shandong Peninsula, and three of them did not make landfall on Shandong Peninsula. The maximum wind speed of Typhoon Muifa and Typhoon Lekima reached $60 \mathrm{~m} / \mathrm{s}$. The maximum wind speed of Typhoon Fengshen, in the Northwest Pacific, was more than $40 \mathrm{~m} / \mathrm{s}$ and lasted $186 \mathrm{~h}$. The 
maximum wind speed of Typhoon Fengshen, in the Northern East China Sea, was $30 \mathrm{~m} / \mathrm{s}$. Both Typhoon Muifa and Typhoon Lekima both tracked due north. Therefore, we decided to use data from Typhoon Muifa and Typhoon Lekima to investigate a typhoon intensity and its effects in the Northern East China Sea.

Table 1. Maximum wind speed, strong wind duration, and landfall information for 12 typhoons that have passed through the Northern East China Sea. Data is from CMA Tropical Cyclone Data Center [32].

\begin{tabular}{cccccc}
\hline $\begin{array}{c}\text { Typhoon } \\
\text { Number }\end{array}$ & $\begin{array}{c}\text { Typhoon } \\
\text { Name }\end{array}$ & $\begin{array}{c}\text { Maximum Wind } \\
\mathbf{( m / s )}\end{array}$ & $\begin{array}{c}\text { Duration of Wind } \\
\text { above } \mathbf{4 0} \mathbf{~ m} / \mathbf{s} \mathbf{( h )}\end{array}$ & $\begin{array}{c}\text { Duration of Winds } \\
\text { above } \mathbf{6 0} \mathbf{~ m} / \mathbf{s} \text { (h) }\end{array}$ & $\begin{array}{c}\text { Landfall on } \\
\text { Shandong Peninsula }\end{array}$ \\
\hline 200004 & Kai_Tai & 35 & 0 & 0 & $\mathrm{~N}$ \\
200209 & Fengshen & 55 & 186 & 0 & $\mathrm{Y}$ \\
200509 & Matsa & 45 & 66 & 0 & $\mathrm{Y}$ \\
200515 & Khanun & 50 & 54 & 0 & $\mathrm{~N}$ \\
200713 & Wipha & 55 & 30 & 0 & $\mathrm{Y}$ \\
201105 & Meari & 30 & 0 & 0 & $\mathrm{~N}$ \\
201109 & Muifa & 65 & 144 & 6 & $\mathrm{Y}$ \\
201210 & Damrey & 40 & 6 & 0 & $\mathrm{Y}$ \\
201410 & Matmo & 42 & 18 & 0 & $\mathrm{Y}$ \\
201810 & Ampil & 28 & 0 & 0 & $\mathrm{Y}$ \\
201818 & Rumbia & 25 & 0 & 3 & $\mathrm{Y}$ \\
201909 & Lekima & 62 & 63 & & \\
\hline
\end{tabular}

Previous studies have determined that the maximum wind speed, radius of maximum wind, translation speed, and incident angle are important factors in numerically simulating typhoon-induced storm surges and significant wave heights [33-35]. Typhoon Muifa and Typhoon Lekima were chosen for comparison, because they had the same angle of incidence and similar paths, although one made landfall at Shandong Peninsula and the other did not. This study chose three characteristics as the typhoon intensity parameters: maximum wind speed, radius, and typhoon translation speed.

The remainder of the paper is organized as follows: Section 2 includes data resources and methodology, such as model description, model setup, experimental design, and methodology. Next, Section 3 presents the model verification and the results of the experiments. Section 4 contains the discussion of disaster-causing mechanisms, the effects of the three typhoon disaster factors, and a comparative study of the effects of a typhoon's path. Finally, in Section 5, we summarize the main findings and provide guidance for government departments on preventing disasters and reducing damage.

\section{Data and Methodology}

\subsection{Model Description}

\subsubsection{SWAN}

The Simulation Waves Nearshore (SWAN) model was designed by the Delft University of Technology [36]. This model is a third-generation numerical simulation wave model for shallow water areas that has been widely used in recent years $[37,38]$. The control equation for SWAN can be used in a Cartesian coordinate system and a spherical coordinate frame. In a Cartesian coordinate system, it can be shown as the following equation:

$$
\frac{\partial \mathrm{N}}{\partial \mathrm{t}}+\frac{\partial}{\partial \mathrm{x}} \mathrm{C}_{\mathrm{x}} \mathrm{N}+\frac{\partial}{\partial \mathrm{y}} \mathrm{C}_{\mathrm{y}} \mathrm{N}+\frac{\partial}{\partial \sigma} \mathrm{C}_{\sigma} \mathrm{N}+\frac{\partial}{\partial \theta} \mathrm{C}_{\theta} \mathrm{N}=\frac{\mathrm{S}_{\text {tot }}}{\sigma},
$$

where $t$ represents time; $x$ and $y$ are geographical coordinates; $\theta$ is the direction of wave propagation; $\sigma$ is the relative frequency of a wave; $\mathrm{N}$ is wave action density; and $\mathrm{S}_{\text {tot }}$ represents sources and exports, including six processes, such as wind input, nonlinear energy transfer term caused by three waves interacting, nonlinear energy transfer term caused by four waves interacting, white hat dissipation, wave energy dissipation due to 
low friction, and energy dissipation of wave breaking due to shallower water depths. This model has widely applied in oceans around the globe [39-44]. Therefore, the SWAN model can simulate wave heights more accurately and reasonably.

\subsubsection{ADCIRC}

The Advanced Circulation (ADCIRC) model was developed by the University of North Carolina and Notre Dame University [45-47]. The ADCIRC model is an advanced hydrodynamic model that can be applied to computational domains encompassing coastal seas and small-scale estuarine systems. GWCEs (Generalized Wave Continuity Equations) were used in the ADCIRC model, which can be shown using the equations below:

$$
\begin{gathered}
\frac{\partial \eta}{\partial t}+\frac{\partial H u}{\partial x}+\frac{\partial H v}{\partial y}=0, \\
\frac{d u}{d t}=f v-g \frac{\partial\left[\eta+\frac{P_{s}}{g \rho_{0}}\right]}{\partial x}+\frac{\tau_{s x}-\tau_{b x}}{\rho_{0} H}+\frac{M_{x}}{H}, \\
\frac{d v}{d t}=-f u-g \frac{\partial\left[\eta+\frac{P_{s}}{g \rho_{0}}\right]}{\partial y}+\frac{\tau_{s y}-\tau_{b y}}{\rho_{0} H}+\frac{M_{y}}{H},
\end{gathered}
$$

where $\eta$ is free surface elevation, $t$ is time, $H$ is the total depth of the water, $u$ and $v$ represent flow speed $\mathrm{y}$ in directions $\mathrm{x}$ and $\mathrm{y}, \mathrm{f}$ is the Coriolis parameter, $\mathrm{g}$ is the acceleration of gravity, $P_{s}$ is pressure on sea surface, $M_{x}$ and $M_{y}$ are the diffusion terms of horizontal momentum in directions $x$ and $y, \tau_{s x}$ and $\tau_{b x}$ are components of surface stress in directions $\mathrm{x}$ and $\mathrm{y}$, and $\tau_{\mathrm{sy}}$ and $\tau_{\mathrm{by}}$ are components of bottom stress in directions $\mathrm{x}$ and $\mathrm{y}$.

The ADCIRC model can acquire data on the water level and water flow using the finite element method in an unstructured triangular mesh grid. This method has been widely used in the simulation and prediction of storm surges [48-51]. The ADCIRC model provides a good simulation of a complex coast.

\subsubsection{The Coupled Model}

Typhoon surge and typhoon wave have interaction effects. In the SWAN + ADCIRC coupled model, the result of wind speed, water level, and water current in each grid point calculated from the ADCIRC model are the input of the SWAN model. The ADCIRC model is also influenced by wave radiation stress calculated from the SWAN model, which can be calculated from the equations below:

$$
\begin{aligned}
& \tau_{\mathrm{sx}, \text { wave }}=-\frac{\partial S_{\mathrm{xx}}}{\partial \mathrm{x}}-\frac{\partial S_{\mathrm{xy}}}{\partial \mathrm{y}}, \\
& \tau_{\mathrm{sy}, \text { wave }}=-\frac{\partial S_{\mathrm{xy}}}{\partial \mathrm{x}}-\frac{\partial S_{\mathrm{yy}}}{\partial \mathrm{y}},
\end{aligned}
$$

where $S_{x x}, S_{x y}$, and $S_{y y}$ are the wave radiation stresses.

Many studies have shown that an unstructured grid is appropriate for simulating hydrodynamic processes for an irregular coastline. The SWAN + ADCIRC coupled model runs on an unstructured grid and has been widely used in calculating storm surges and significant wave heights [38,50-56]. Therefore, in this study, we used the SWAN + ADCIRC model as our simulation model.

\subsection{Model Setup}

The wind field and pressure field data for Typhoon Muifa and Typhoon Lekima can be obtained from the fifth-generation European Centre for Medium-Range Weather Forecasts (ECMWF) atmospheric reanalysis of the global climate (ERA5). The time resolution of this data was $1 \mathrm{~h}$, and the spatial resolution was in $0.25^{\circ}$ (approximately $30 \mathrm{~km}$ ). ECMWF was wildly used in the numerical simulations [20-25,57-59]. Meng [60] compared the 
ERA5 product with the observations and found that ERA5 matched better than the ERAInterim product in Shandong Province and the surrounding areas. Li [61] simulated a significant wave height and storm surge using the ERA5 reanalysis product and verified that the ERA5 product agreed well with the observations in the coastal seas of China. The large wave simulation of Typhoon Lekima was demonstrated by Hsiao [25] using the ERA5 product. Though hybrid methods, which combined the reanalysis product with a parametric typhoon model to obtain the typhoon wind field, have been used to simulate the marine dynamical processes in many studies $[13,15,21-23,62]$, they were not applicable or fit less well than ERA5 in the Northern East China Sea. Therefore, this study used the ERA5 reanalysis product to build the wind forcing.

The coastline data were derived from the Global Self-consistent, Hierarchical, Highresolution Geography Database (GSHHG) coastline resources. The bathymetry data were provided by The General Bathymetric Chart of the Oceans (GEBCO), with a resolution of 30". The buoy and tide gauge datasets used in this study are available from the corresponding author upon request.

In this study, the ADCIRC model was set to two-dimensional mode in a spherical coordinate frame. $\beta$ planar approximation was used in Coriolis force. The initial water level and flow velocity was set to 0 . The model's only open boundary was driven by harmonic constants of the eight main astronomical constituents, including $\mathrm{K} 1, \mathrm{~K} 2, \mathrm{M} 2, \mathrm{~N} 2, \mathrm{O} 2, \mathrm{P} 1$, $\mathrm{Q} 1$, and S2. The SWAN model was set to the two-dimensional nonstationary mode. The initial condition $\mathrm{H}$ was set to zero. The coupled model output result was set to $1 \mathrm{~h}$.

For Typhoon Muifa, the calculated time was from 0:00 on 4 August 2011 to 23:00 on 9 August 2011. For Typhoon Lekima, the calculated time was from 0:00 on 9 August 2019 to 23:00 on 13 August 2011.

\subsection{Experimental Design}

\subsubsection{Maximum Wind Speed of Typhoons}

According to previous studies [33,34], the maximum wind speed of a typhoon is one of the most important factors in affecting a typhoon-induced storm surge. The higher the maximum wind speed of a typhoon is, the more serious damage it may cause $[14,15,33-35,63]$.

In this study, eight experiments on maximum wind speed were designed from Typhoon Muifa and Typhoon Lekima, respectively, to investigate the impacts of a typhoon that made landfall and a typhoon that did not make landfall using the results of the SWAN + ADCIRC model, which are shown in Table 2. In these sensitive experiments, the maximum wind speed $\left(\mathrm{V}_{\max }\right)$ of Typhoon Muifa and Typhoon Lekima were set at $10 \mathrm{~m} / \mathrm{s}$, $20 \mathrm{~m} / \mathrm{s}, 25 \mathrm{~m} / \mathrm{s}, 30 \mathrm{~m} / \mathrm{s}, 35 \mathrm{~m} / \mathrm{s}, 40 \mathrm{~m} / \mathrm{s}$, and $50 \mathrm{~m} / \mathrm{s}$. The normalized wind speed and modified wind forcing were calculated from the equations below:

$$
\begin{aligned}
\overrightarrow{\mathrm{V}}_{\text {nor }}(\mathrm{r}, \mathrm{t}) & =\frac{\mathrm{V}_{\max }-\overrightarrow{\mathrm{V}}(\mathrm{r}, \mathrm{t})}{\mathrm{V}_{\max }-\mathrm{V}_{\min }}, \\
\alpha & =\frac{\mathrm{V}_{\exp }}{\mathrm{V}_{\max }}, \\
\overrightarrow{\mathrm{V}}^{\prime}(\mathrm{r}, \mathrm{t}) & =\alpha \overrightarrow{\mathrm{V}}_{\text {nor }}(\mathrm{r}, \mathrm{t})
\end{aligned}
$$

where $\vec{V}(r, t)$ was the reanalysis winds, $\vec{V}^{\prime}(r, t)$ was the modified wind forcing, $t$ was the time, $r$ was the distance from the typhoon central to an arbitrary point. $V_{\max }=\max (|\vec{V}(r, t)|)$ and $V_{\min }=\min (|\vec{V}(r, t)|) \cdot V_{\text {exp }}$ was the maximum wind speed in experiments 1-8 in the case of Typhoon Muifa and in experiments 18-25 in the case of Typhoon Lekima. Moreover, the typhoon center information of two hurricanes were extracted from the mean sea level pressure (MSL) of ERA5. Comparison results could indicate good agreement between the hourly extracted information and validation data from Japan Meteorological Agency 
(JMA), with an interval time of $6 \mathrm{~h}$. Therefore, this study used hourly extracted typhoon road information.

Table 2. Design of the sensitivity experiments. In each experiment, only one parameter was varied.

\begin{tabular}{ccccc}
\hline Typhoon & MUIFA & \multicolumn{2}{c}{ LEKIMA } \\
\hline Variate & Number & Value & Number & Value \\
\hline & 1 & 10 & 18 & 10 \\
& 2 & 20 & 19 & 20 \\
Max Wind Speed & 3 & 25 & 20 & 25 \\
(m/s) & 4 & 30 & 21 & 30 \\
& 5 & 35 & 22 & 35 \\
& 6 & 40 & 23 & 40 \\
& 7 & 45 & 24 & 45 \\
& 8 & 50 & 25 & 50 \\
\hline Radius $(\mathrm{km})$ & 9 & 10 & 26 & 10 \\
& 10 & 20 & 28 & 30 \\
& 11 & 30 & 29 & 40 \\
& 12 & 40 & 30 & 50 \\
Translation & 13 & 50 & 31 & 7.5 \\
Speed (km/s) & 14 & 3.5 & 33 & 30 \\
& 15 & 15 & 34 & 60 \\
\hline
\end{tabular}

Holland proved that a higher maximum wind speed value may appear when the typhoon center pressure is lower [51]. The relationship between the maximum wind speed and minimum central pressure in tropical cyclones has been proposed in previous studies [64,65], and Harper [66] concluded the form of pressure-wind models. Li [15] modified the central pressure using the relationship between $V_{\max }$ and typhoon center pressure. Therefore, a mathematical relationship can be inferred between the minimum pressure at the typhoon center and maximum wind speed around the typhoon center. This study used a formula relating the minimum central pressure and maximum surface winds in tropical cyclones, which was proposed by Knaff [67] and is shown below:

$$
\mathrm{V}_{\max }=2.3\left(1010-\mathrm{P}_{\mathrm{c}}\right)^{0.76},
$$

where $\mathrm{P}_{\mathrm{c}}$ is the typhoon center pressure. Minimum pressures in the typhoon center are listed in Table 3.

Table 3. Maximum wind speed and central pressure of the typhoons in the experiments of the maximum wind speed.

\begin{tabular}{ccccccccc}
\hline Maximum Wind Speed (m/s) & 10 & 20 & 25 & 30 & 35 & 40 & 45 & 50 \\
\hline Minimum Pressure (hPa) & 1003 & 993 & 987 & 981 & 974 & 967 & 960 & 953 \\
\hline
\end{tabular}

\subsubsection{The Radius of Maximum Wind}

Typhoon size has an important impact on the disasters of wave and surge [35,68-70]. Irish [69] found that a storm surge could vary $30 \%$ within a reasonable range of radius of the maximum wind.

In this study, we chose the radius of maximum wind as the reference factor to study the impact of the typhoon size. As shown in Table 2, a modified wind field was calculated from the equations below:

$$
\beta=\frac{R_{\exp }}{R_{\max }}
$$




$$
\overrightarrow{\mathrm{V}}^{\prime}(\mathrm{r}, \mathrm{t})=\overrightarrow{\mathrm{V}}(\beta \mathrm{r}, \mathrm{t})
$$

where $R_{\max }$ was the maximum distance between the typhoon center and the location of maximum wind speed during Typhoons Muifa and Lekima, and $R_{\exp }$ was the radius of maximum wind in experiments 9-13 in the case of Typhoon Muifa and in experiments $26-30$ in the case of Typhoon Lekima and set as $10 \mathrm{~km}, 20 \mathrm{~km}, 30 \mathrm{~km}, 40 \mathrm{~km}$, and $50 \mathrm{~km}$, respectively.

\subsubsection{The Typhoon Translation Speed}

A typhoon wind field is a vortex structure with strong horizontal shearing forces. The wave field and storm surge fields change due to the motion of the typhoon center and changes in the local wind field. Previous studies have shown that the translation speed of a typhoon could influence the height of the storm surge, the reaching time of the high surge, and the duration of flooding [34,63]. Zhong [35] halved and doubled the moving speed of Hurricane Isabel and in Chesapeake Bay and concluded that the duration of high water level is much longer than fast translation speed. Therefore, it is important to study the impacts of typhoon translation speed

Based on reanalyzed ERA data, the maximum translation speed of Typhoon Muifa and Typhoon Lekima were $30 \mathrm{~km} / \mathrm{h}$. In this study, the maximum typhoon translation speed of Typhoon Muifa and Typhoon Lekima were set as $7.5 \mathrm{~km} / \mathrm{h}, 15 \mathrm{~km} / \mathrm{h}, 30 \mathrm{~km} / \mathrm{h}$, and $60 \mathrm{~km} / \mathrm{h}$ (Table 2). Modified wind fields were calculated from the equations below:

$$
\overrightarrow{\mathrm{V}}^{\prime}(\mathrm{r}, \mathrm{t})=\overrightarrow{\mathrm{V}}(\mathrm{r}, \gamma \mathrm{t})
$$

where $\gamma$ was set as $0.25,0.5$, and 2 when the typhoon translation speed is $25 \%$ slower, $50 \%$ slower, and $200 \%$ faster in experiments 14 and 31,15 and 32 , and 17 and 34 .

\section{Results}

\subsection{Model Validation}

Typhoon Muifa (2011) was first reported as a tropical disturbance in the Northwest Pacific on 24 June 2011. Muifa was recognized as a typhoon on 30 June, with a trajectory from east of the Philippines to Okinawa-jima. Muifa was recognized as a super typhoon twice, on 30 June and 3 August. After 5 August, the trajectory of Typhoon Muifa went straight north. At 15:00 on 6 August, the center of Typhoon Muifa was at $31.8 \mathrm{~N}$ and $124.4 \mathrm{E}$, south of Shandong Province. On 8 August, Typhoon Muifa was downgraded to a tropical storm and made landfall northwest of North Korea. The trajectory and maximum wind speed of Typhoon Muifa are shown in Figure 2a.

Typhoon Lekima (2019) was recognized as a strong tropical storm by the National Meteorological Centre on 6 August. Typhoon Lekima passed through the South China Sea near the Japanese island of Miyako and made landfall at Zhejiang Province at 1:00 on 10 August. On 11 August, Typhoon Lekima left Jiangsu Province and moved to Shandong Province. On the same day, Typhoon Lekima made landfall at Qingdao. On 12 August, Typhoon Lekima passed over Shandong Peninsula and moved to Laizhou Bay. The Japanese Meteorological Agency then confirmed that Typhoon Lekima had disappeared. The trajectory and maximum wind speed of Typhoon Lekima are shown in Figure $2 b$.

The wind speed and significant wave height during Typhoon Muifa and Typhoon Lekima were successfully record by buoys whose locations are shown in Figure 3 (QF101, QF103, QF104, and QF114). The storm surges were successfully recorded at several stations near Shandong Province, whose locations are also shown in Figure 3 (HHG station, WFG station, LKO station, WMT station, and RZH station). Figure 4 shows the wind speed fitting result between the observed data and ERA5. Figures 5 and 6 show the observed and simulated data of a significant wave height and storm surge. In brief, all these observed data were successfully measured in extremis when Typhoon Muifa and Typhoon Lekima passed by the Northern East China Sea. 


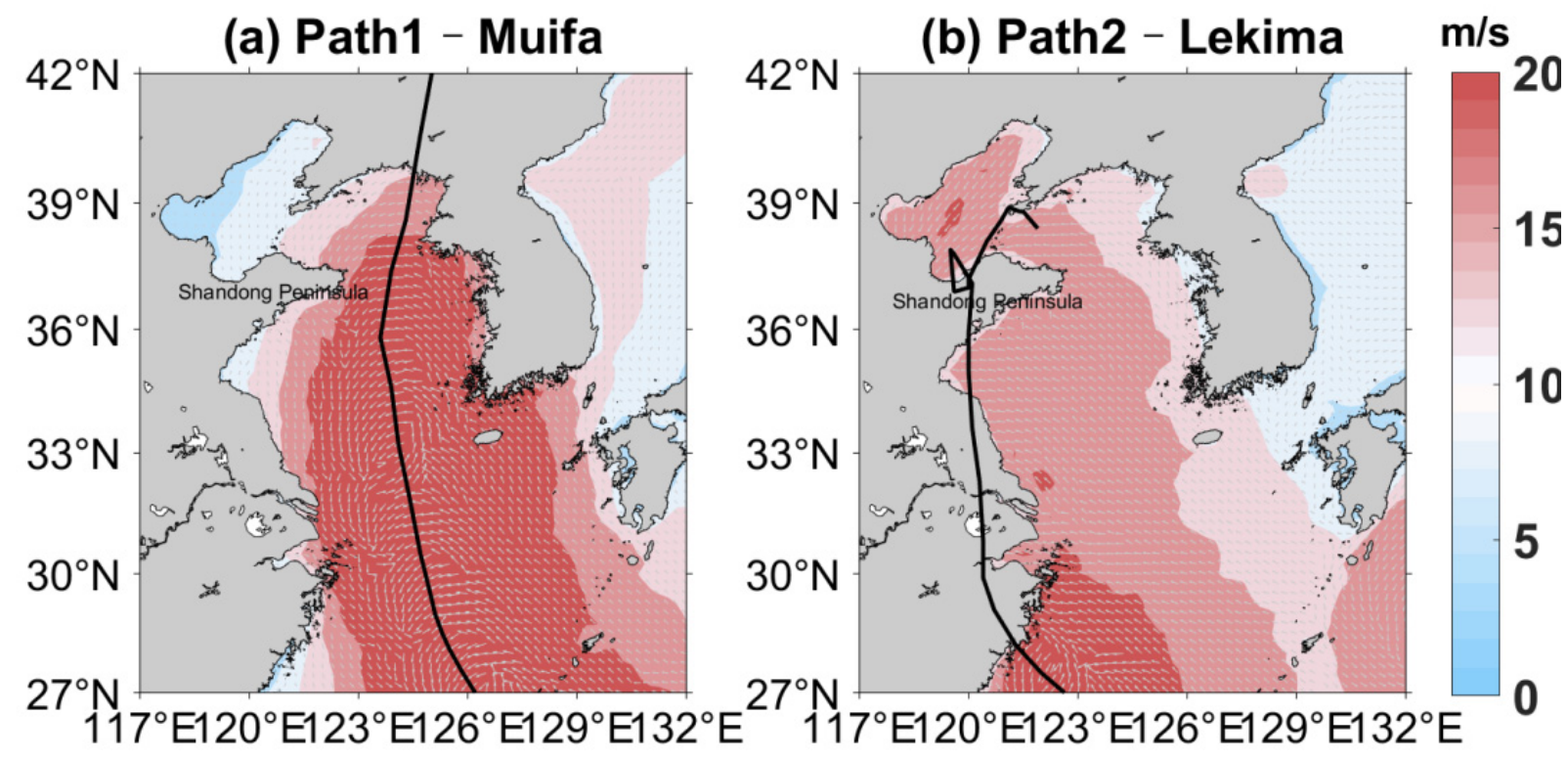

Figure 2. The maximum wind speed field vector diagram of (a) Typhoon Muifa and (b) Typhoon Lekima over the entire typhoon events.

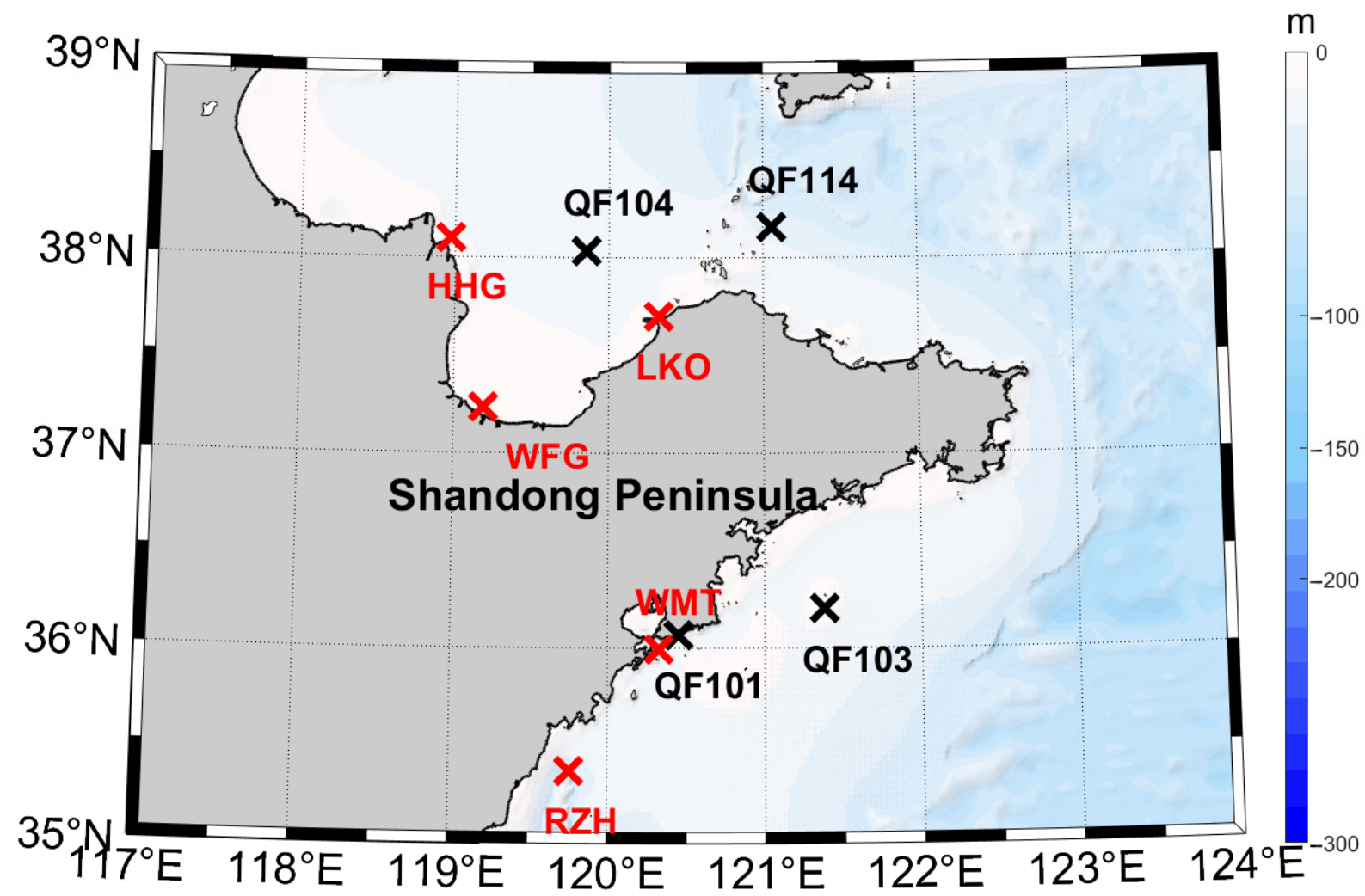

Figure 3. Landforms of the Northern East China Sea. Locations of buoys (QF101, QF103, QF104, and QF104) and stations (HHG, WFG, LKO, WMT, and RZH) are marked. 

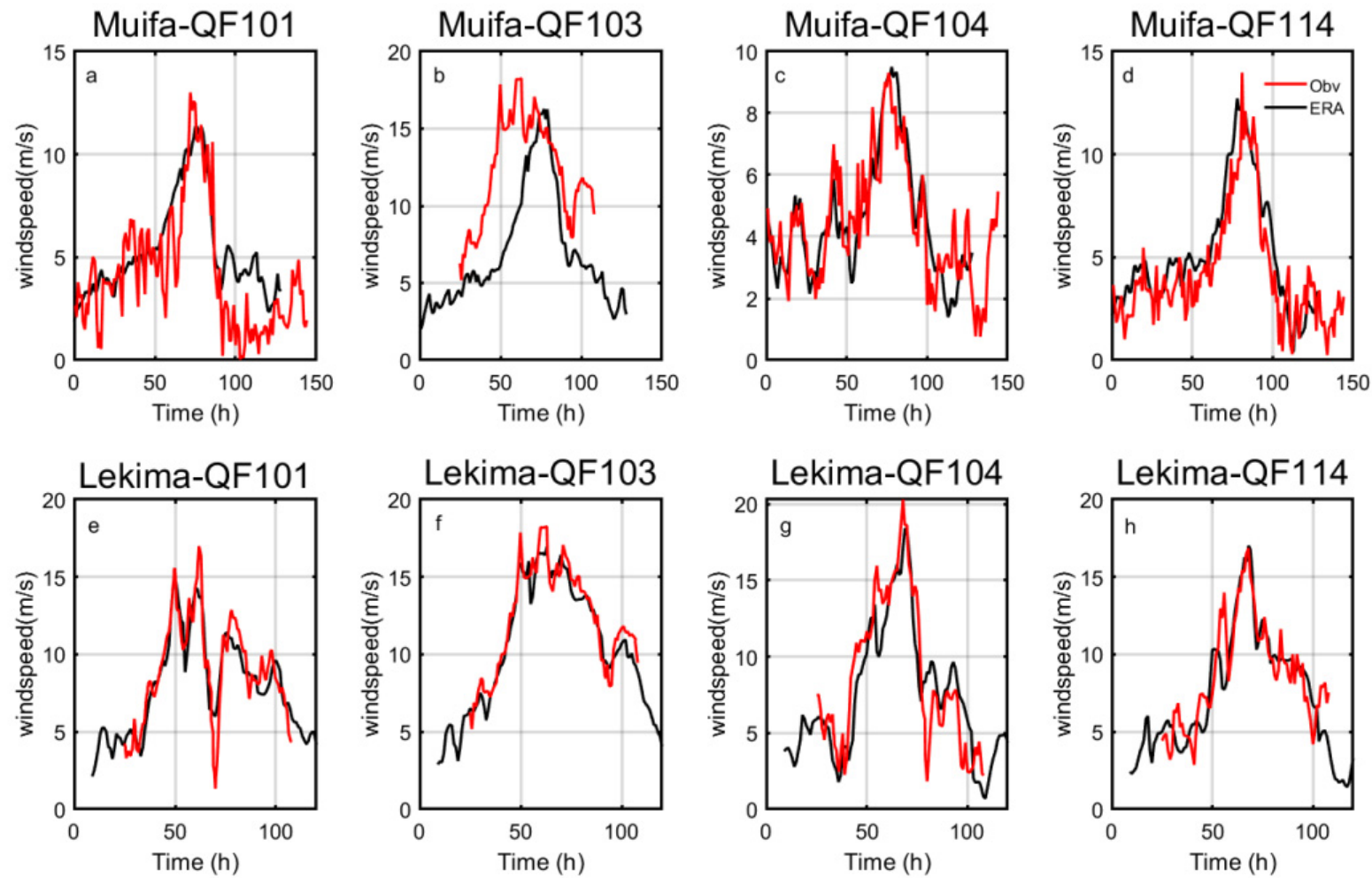

Figure 4. Reanalyzed ERA data and observations of the wind speed of Typhoon Muifa (a-d) and Typhoon Lekima (e-h) at buoys (a,d) QF101, (b,f) QF103, (c,g) QF104, and (d,h) QF114. The red line represents observations, and the black line represents reanalyzed data from ERA5.
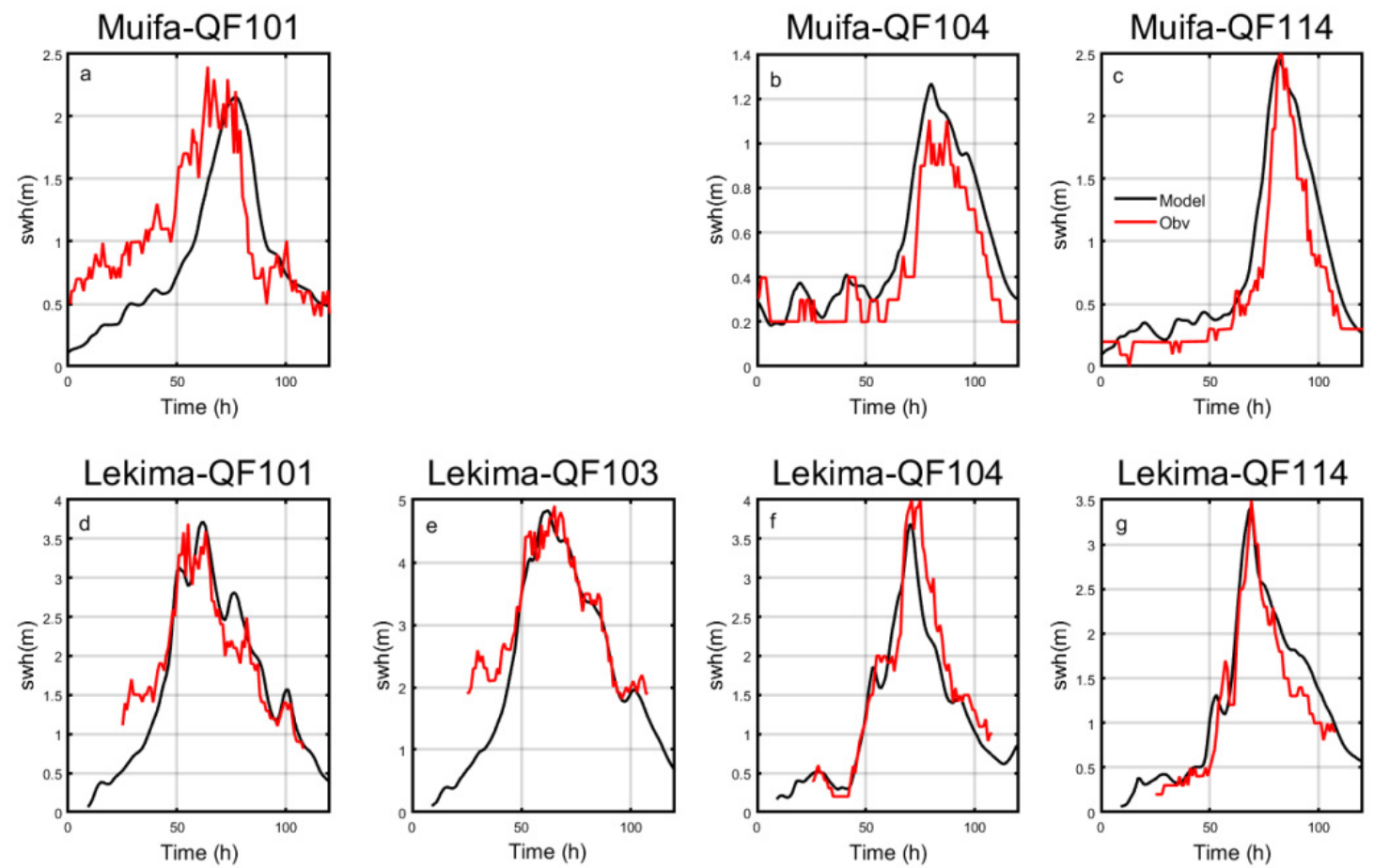

Figure 5. Simulation and observations of a significant wave height of Typhoon Muifa (a-c) and Typhoon Lekima (d-g) at buoys (a,d) QF101, (e) QF103, (b,f) QF104, and (c,g) QF114. The red line represents observations, and the black line represents reanalyzed data from ERA5. 

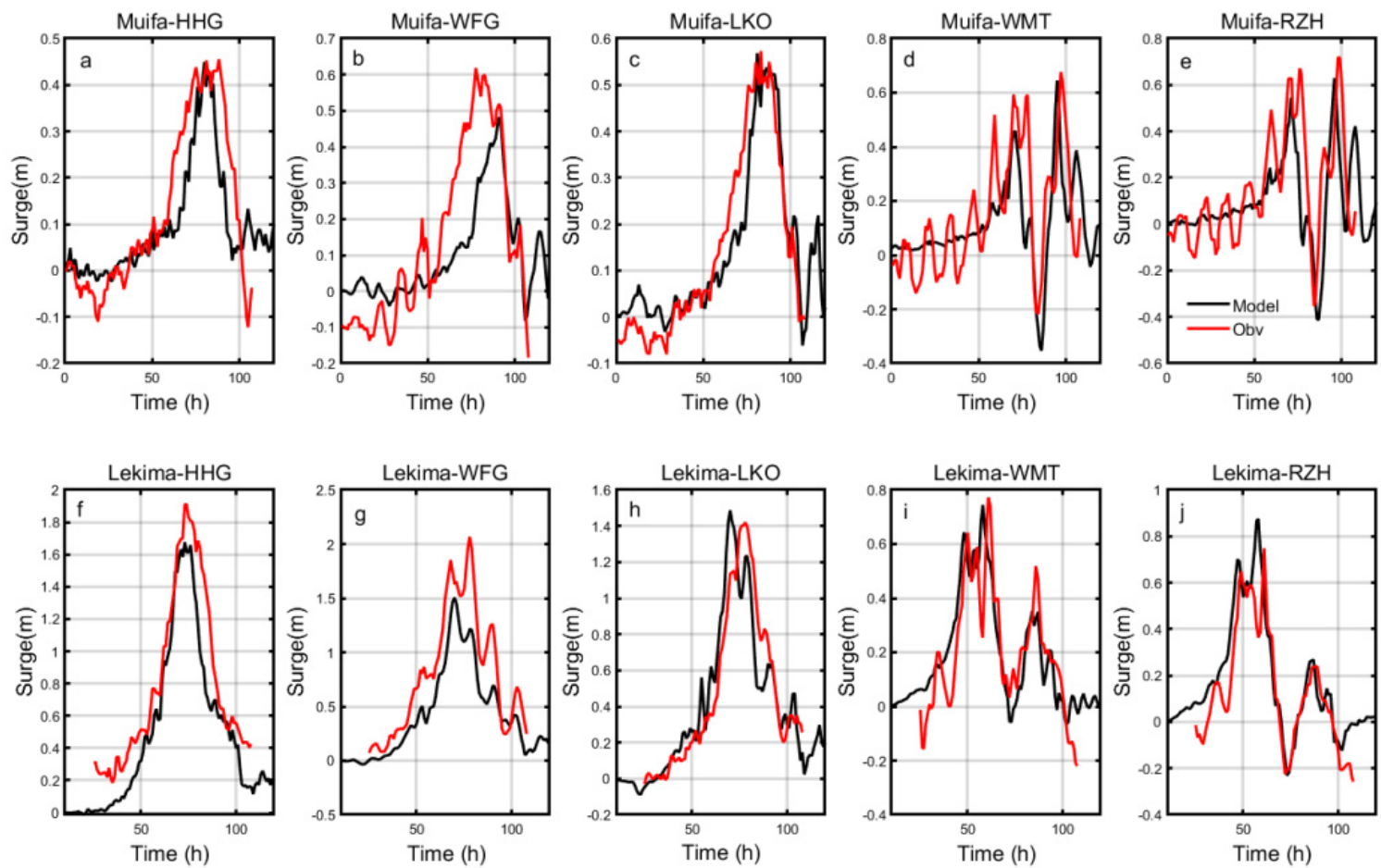

Figure 6. Simulation and observations of the storm surge of Typhoon Muifa (a-e) and Typhoon Lekima $(\mathbf{f}-\mathbf{j})$ at stations $(\mathbf{a}, \mathbf{f})$ HHG, $(\mathbf{b}, \mathbf{g})$ WFG, $(\mathbf{c}, \mathbf{h})$ LKO, $(\mathbf{d}, \mathbf{i})$ WMT, and $(\mathbf{e}, \mathbf{j})$ RZH. The red line represents observations, and the black line represents simulations calculated with the SWAN + ADCIRC model.

Table 4 lists the absolute error and relative error between the observed data and ERA5 data on wind speed. The absolute error and relative error were calculated from the equation shown below:

$$
\begin{aligned}
& \mathrm{AE}=\frac{1}{n} \sum_{\mathrm{i}=1}^{\mathrm{n}}\left|\mathrm{x}_{\mathrm{i}}-\mathrm{y}_{\mathrm{i}}\right|, \\
& \mathrm{RE}=\frac{1}{\mathrm{n}} \sum_{\mathrm{i}=1}^{\mathrm{n}} \frac{\left|\mathrm{x}_{\mathrm{i}}-\mathrm{y}_{\mathrm{i}}\right|}{\mathrm{x}_{\mathrm{i}}},
\end{aligned}
$$

where $x_{i}$ is the ERA5 data, $y_{i}$ is the observed data, and $n$ is data length.

Table 4. The absolute error and relative error between the observed data and ERA5 reanalyzed data for the wind speed at four stations (QF101, QF103, QF104, and QF114) during Typhoon Muifa and Typhoon Lekima. Significant digits are reserved to three decimal places.

\begin{tabular}{lcccc}
\hline Typhoon & Typhoon Muifa & \multicolumn{3}{c}{ Typhoon Lekima } \\
\hline Station & Absolute Error $(\mathbf{m})$ & Relative Error & Absolute Error $(\mathbf{m})$ & Relative Error \\
\hline QF101 & 1.014 & 0.221 & -0.085 & -0.003 \\
QF103 & -3.686 & -0.565 & -0.381 & -0.035 \\
QF104 & -0.109 & -0.108 & -0.207 & -0.123 \\
QF114 & 0.681 & 0.094 & -0.285 & -0.076 \\
\hline
\end{tabular}

Table 5 lists the absolute error and relative error between the observed data and simulated data for a significant wave height. Table 6 lists the absolute error and relative error between the observed data and simulation data for a storm surge. These data imply that the model results fit the observed data. Therefore, the results imply that using ERA5 data in the Northern East China Sea is reasonable, as well as that the simulation results of the SWAN + ADCIRC model are convincing and could be used in sensitivity experiments. 
Table 5. The absolute error and relative error between the observed data and ERA5 reanalyzed data for a significant wave height at four stations (QF101, QF103, QF104, and QF114) during Typhoon Muifa and Typhoon Lekima. Significant digits are limited to three decimal places.

\begin{tabular}{lcccc}
\hline Typhoon & Typhoon Muifa & \multicolumn{3}{c}{ Typhoon Lekima } \\
\hline Station & Absolute Error $(\mathbf{m})$ & Relative Error & Absolute Error (m) & Relative Error \\
\hline QF101 & -0.218 & -0.693 & -0.012 & -0.113 \\
QF103 & & & -0.348 & -0.318 \\
QF104 & 0.136 & 0.214 & -0.178 & -0.090 \\
QF114 & 0.255 & 0.276 & 0.184 & 0.139 \\
\hline
\end{tabular}

Table 6. The absolute error and relative error between the observed data and ERA5 reanalyzed data for a storm surge at five stations (HHG, WFG, LKO, WMT, and RZH) during Typhoon Muifa and Typhoon Lekima. Significant digits are limited to three decimal places.

\begin{tabular}{lcccc}
\hline Typhoon & Typhoon Muifa & \multicolumn{3}{c}{ Typhoon Lekima } \\
\hline Station & Absolute Error $(\mathbf{m})$ & Relative Error & Absolute Error $(\mathbf{m})$ & Relative Error \\
\hline HHG & -0.008 & -7.845 & -0.208 & -3.31 \\
WFG & -0.034 & 3.048 & -0.207 & 0.010 \\
LKO & 0.014 & 0.515 & -0.010 & 0.218 \\
WMT & -0.032 & 0.261 & 0.028 & 6.524 \\
RZH & -0.017 & -4.639 & 0.078 & -0.923 \\
\hline
\end{tabular}

\subsection{Maximum Wind Speed}

Previous work has shown that the wind input is important for model simulation [49]. The higher the maximum wind speed, the larger the area of significant wave height will be (Figure 7). In experiments based on Typhoon Muifa, an area with a significant wave height smaller than $4 \mathrm{~m}$ was distributed in the Yellow Sea when the maximum wind speed was lower than $30 \mathrm{~m} / \mathrm{s}$. A higher significant wave height was located to the west of the typhoon's path. When maximum wind speed was greater than $30 \mathrm{~m} / \mathrm{s}$, the typhoon's energy spread in a radial pattern from north of the Yellow Sea through the Bohai Strait into the Bohai Sea. As the maximum wind speed increased, the area with significant wave height above six meters increased rapidly in the Northern Yellow Sea and slowly in Haizhou Bay due to their topographies. Figure 8 presents a significant wave height over time at four buoys (QF101, QF103, QF104, and QF114). From Figure 8a-d, it can be seen that the time curve of a significant wave height had only one large pulse. The higher the wind speed, the greater the significant wave height. Though different maximum wind speed experiments led to different extreme values, their variation tendencies were similar. A strong wind force intensified the waves. The extreme values shifted to an earlier time as the maximum wind speed increased.

In experiments based on Typhoon Lekima, a higher maximum wind speed led to higher significant wave heights. This is the same pattern seen with Typhoon Muifa. However, the difference between experiments based on Typhoon Muifa and Typhoon Lekima was the area with a high value for a significant wave height occurred in the Bohai Sea and the Yellow Sea at the same time in the case of Typhoon Lekima. When the maximum wind speed was less than $25 \mathrm{~m} / \mathrm{s}$, a high value of a significant wave height occurred in both the Bohai Sea and the Yellow Sea. In the Bohai Sea, the area with the greatest significant wave height was between Bohai Bay and Laizhou Bay. This is because the path of Lekima passed through Shandong Peninsula. When the maximum wind speed was up to $30 \mathrm{~m} / \mathrm{s}$, two areas with a wave height above $5 \mathrm{~m}$ were combined through the Bohai Strait. During Typhoon Lekima, the maximum wind speed showed a strong positive with respect to a significant wave height (Figure 8), which was the same as the pattern seen during Typhoon Muifa. The greater the maximum wind speed value was, the greater the significant wave height. The experiments showed a similar variation tendency. 

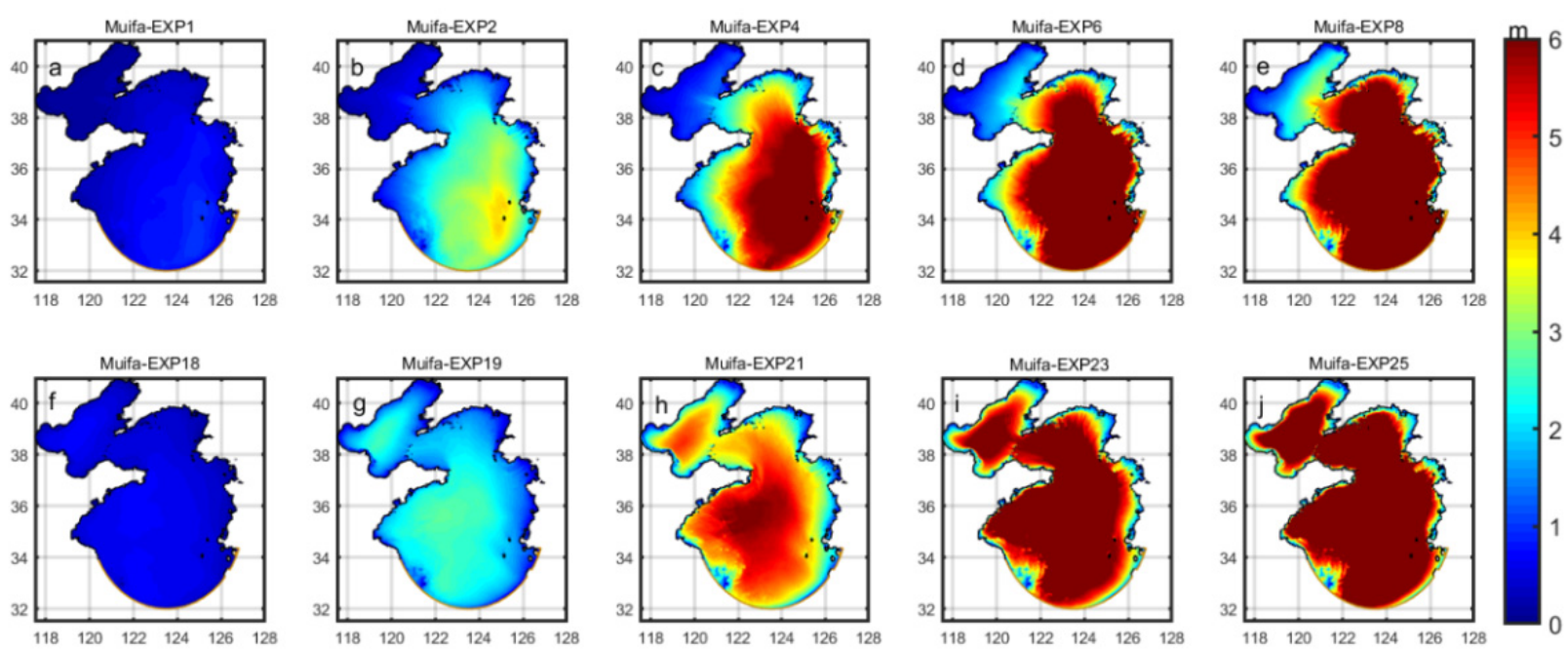

Figure 7. Spatial distribution of a significant wave height when the maximum wind speed was (a) $10 \mathrm{~m} / \mathrm{s}$, (b) $20 \mathrm{~m} / \mathrm{s}$, (c) $30 \mathrm{~m} / \mathrm{s}$, (d) $40 \mathrm{~m} / \mathrm{s}$, and (e) $50 \mathrm{~m} / \mathrm{s}$ based on Typhoon Muifa and (f) $10 \mathrm{~m} / \mathrm{s}$, (g) $20 \mathrm{~m} / \mathrm{s}$, (h) $30 \mathrm{~m} / \mathrm{s}$, (i) $40 \mathrm{~m} / \mathrm{s}$, and (j) $50 \mathrm{~m} / \mathrm{s}$ based on Typhoon Lekima.
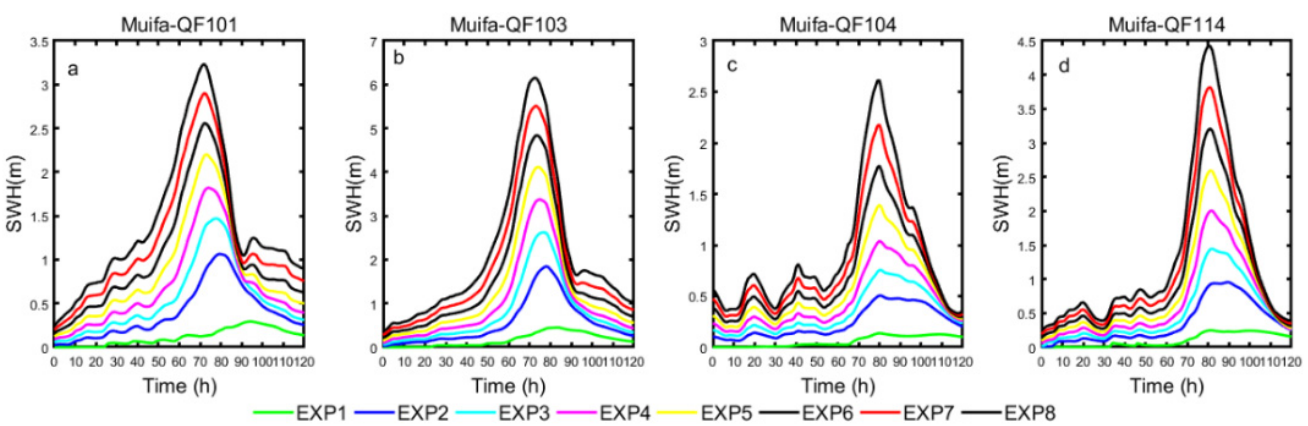

Lekima-QF101
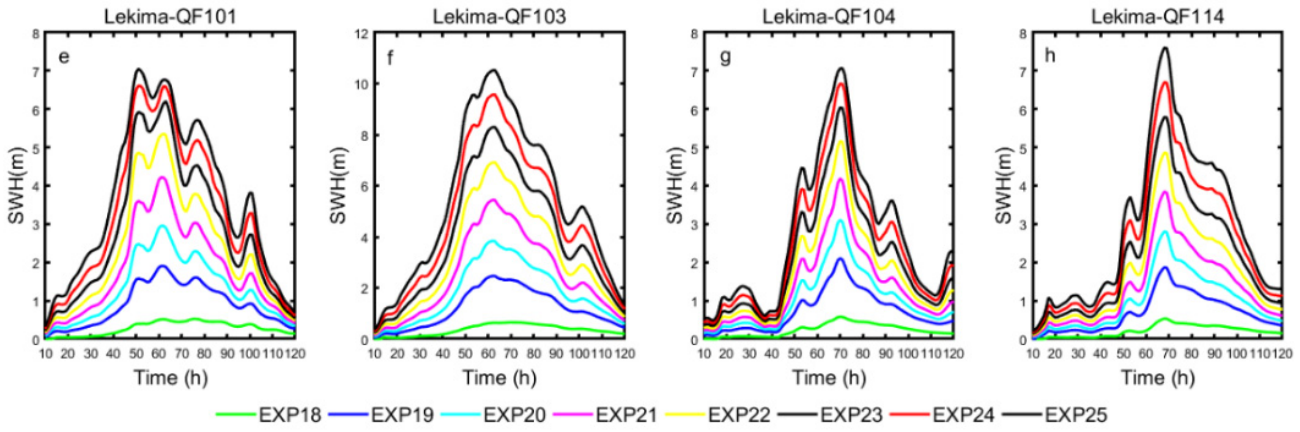

Figure 8. Significant wave height associated with the maximum wind speed over time at (a) QF101, (b) QF103, (c) QF104, and (d) QF114 for Typhoon Muifa and (e) QF101, (f) QF103, (g) QF104, and (h) QF114 for Typhoon Lekima.

Figure 9a-d shows the spatial distribution of the storm surge during Typhoon Muifa. When the maximum wind speed was less than $25 \mathrm{~m} / \mathrm{s}$, the storm surge distribution did not change appreciably. When the maximum wind speed was between $30 \mathrm{~m} / \mathrm{s}$ and $40 \mathrm{~m} / \mathrm{s}$, the storm surge increased in Korea Bay and Gyeonggiman. When the maximum wind speed was higher than $40 \mathrm{~m} / \mathrm{s}$, the storm surge in Korea Bay and Gyeonggiman continued to increase, and the surge in Haizhou Bay increased rapidly. Liaodong Bay, Bohai Bay, and Laizhou Bay had different levels of surging. In Figure 10e-h, the storm surge decreased at first and then increased when the maximum wind speed was less than $25 \mathrm{~m} / \mathrm{s}$ (stations HHG, WFG, and LKO). However, when the maximum wind speed was greater than $25 \mathrm{~m} / \mathrm{s}$, 
the storm surge increased at first and subsequently decreased. At stations WMT and RZH, the maximum wind speed showed the same increasing pattern.
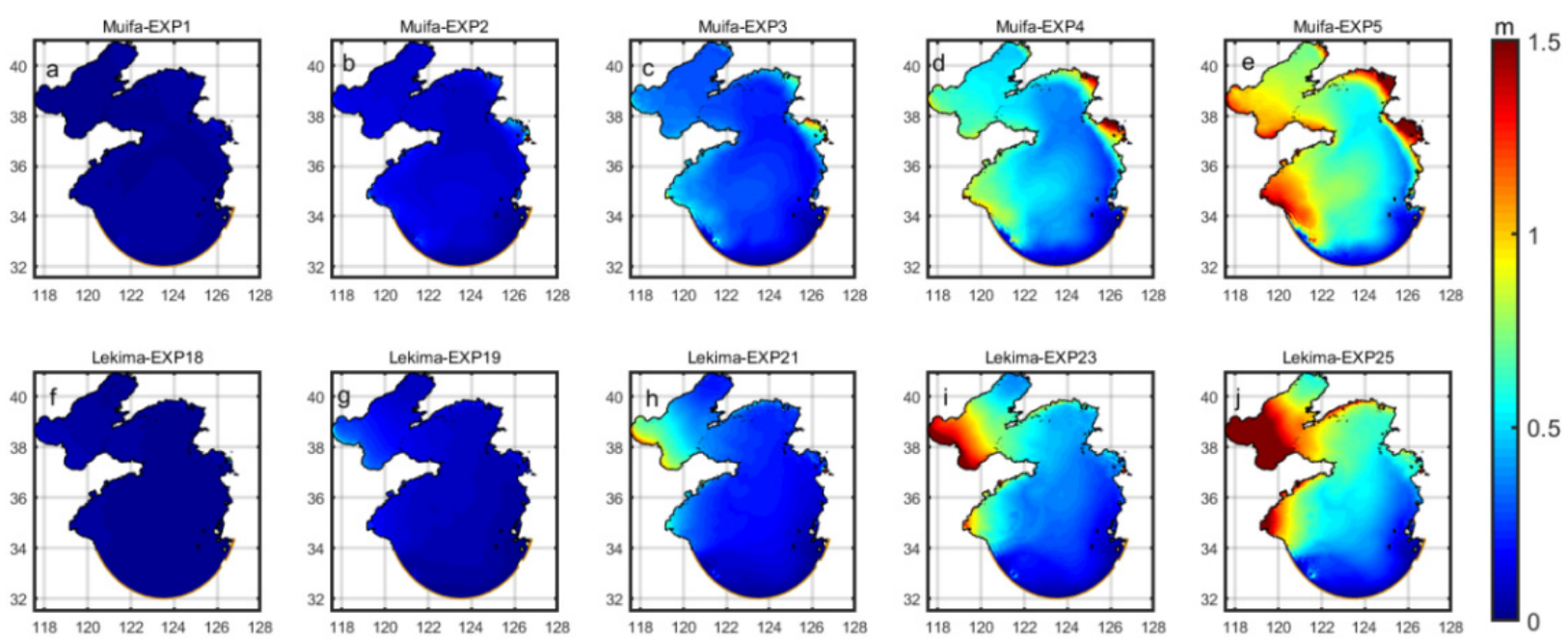

Figure 9. Spatial distribution of the storm surge when the maximum wind speed was (a) $10 \mathrm{~m} / \mathrm{s}$, (b) $20 \mathrm{~m} / \mathrm{s}$, (c) $30 \mathrm{~m} / \mathrm{s}$, (d) $40 \mathrm{~m} / \mathrm{s}$, and (e) $50 \mathrm{~m} / \mathrm{s}$ for Typhoon Muifa and (f) $10 \mathrm{~m} / \mathrm{s},(\mathrm{g}) 20 \mathrm{~m} / \mathrm{s}$, (h) $30 \mathrm{~m} / \mathrm{s}$, (i) $40 \mathrm{~m} / \mathrm{s}$, and (j) $50 \mathrm{~m} / \mathrm{s}$ for Typhoon Lekima.
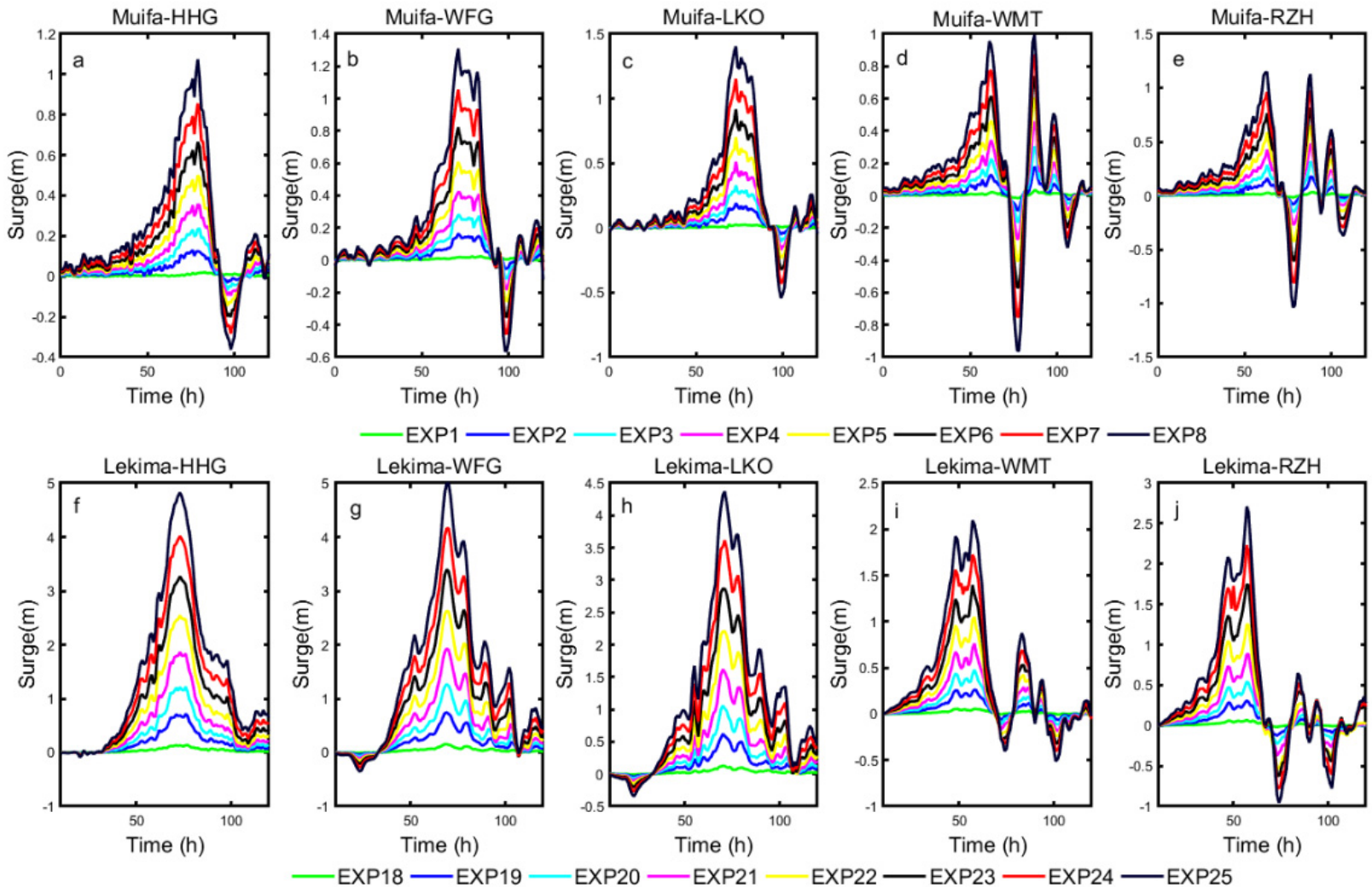

Figure 10. Storm surge associated with the maximum wind speed over time at (a) HHG, (b) WFG, (c) LKO, (d) WMT, and (e) RZH for Typhoon Muifa and (f) HHG, (g) WFG, (h) LKO, (i) WMT, and (j) RZH for Typhoon Lekima.

During Typhoon Lekima, the spatial distribution of the maximum storm surge showed that Bohai Bay, Laizhou Bay, and Haizhou Bay were strongly influenced by the growth of the maximum wind speed. The areas of high surge were larger when the maximum wind 
speed was higher. When the maximum wind speed was less than $30 \mathrm{~m} / \mathrm{s}$, only Bohai Bay and Laizhou Bay were influenced. Haizhou Bay was influenced slowly over time when the maximum wind speed was higher than $30 \mathrm{~m} / \mathrm{s}$. When the maximum wind speed reached $50 \mathrm{~m} / \mathrm{s}$, even the Korean Bay was influenced. As shown in Figure 10, the timing of the storm surge at all stations had the same change pattern. This observation clarified that the maximum wind speed has a positive relationship with the maximum storm surge.

\subsection{Radius of Maximum Wind}

The radius of maximum wind (RMW) is another factor important to a typhoon's intensity [69]. As a typhoon's RMW changes, so does the size of the area influenced as shown in Figure 11. In the case of Typhoon Muifa, the longer the RWM was, the larger the area of impact was. When the RWM of Typhoon Muifa was less than $10 \mathrm{~km}$, the largest significant wave height was located in the middle of the Yellow Sea. When the RMW was higher than $10 \mathrm{~km}$, Haizhou Bay was influenced slowly over time. The magnitude of the significant wave height was influenced not only by RMW but also by the topography. Figure 12 shows significant wave heights at buoys over time. It is clear that the maximum wind speed had a positive relationship with the RMW when the RMW was less than $20 \mathrm{~km}$. In general, a larger typhoon leads to a greater significant wave height. Different buoys showed the same pattern. Due to the geographical location of buoys QF101 and QF103, the initial significant wave height was higher as the typhoon radius was larger. Meanwhile, buoys QF104 and QF114 did not show such a phenomenon. Moreover, the higher maximum significant wave height led to earlier time shifting.

In the simulations of Typhoon Lekima, it can be seen that the influenced area grew larger and stronger as the typhoon's RMW grew larger. However, the significant wave height shown in Figure 12 shows that, though the influenced area shows a strong relative correlation with typhoon radius, two buoys had different patterns. At buoys QF101 and QF114, the maximum significant wave height occurred when Typhoon Lekima's RMW was $40 \mathrm{~km}$. However, at buoys QF103 and QF104, the maximum significant wave height occurred when the RMW of Typhoon Lekima was $30 \mathrm{~km}$.
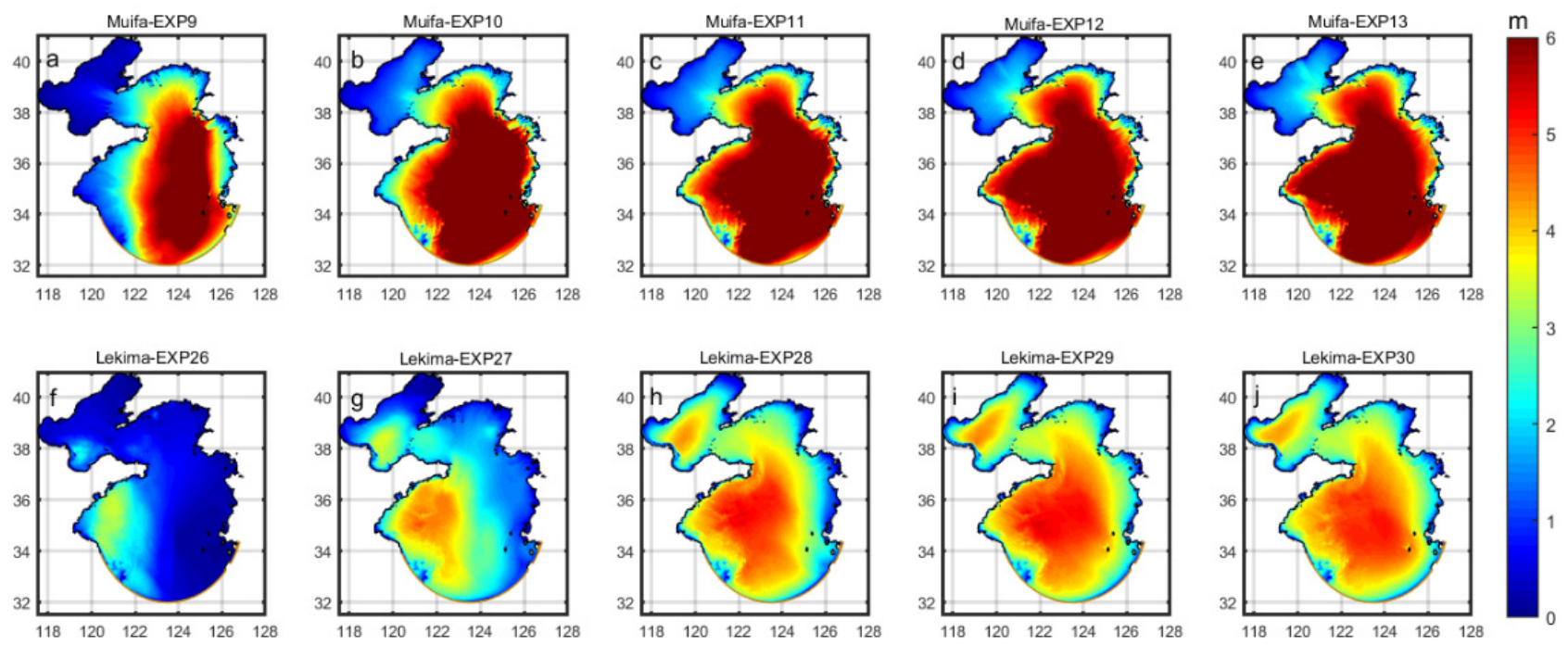

Figure 11. Spatial distribution of the significant wave height when the RMW was (a) $10 \mathrm{~km},(\mathbf{b}) 20 \mathrm{~km}$, (c) $30 \mathrm{~km}$, (d) $40 \mathrm{~km}$, and (e) $50 \mathrm{~km}$ based on Typhoon Muifa and (f) $10 \mathrm{~km},(\mathrm{~g}) 20 \mathrm{~km},(\mathrm{~h}) 30 \mathrm{~km}$, (i) $40 \mathrm{~km}$, and (j) $50 \mathrm{~km}$ based on Typhoon Lekima. 

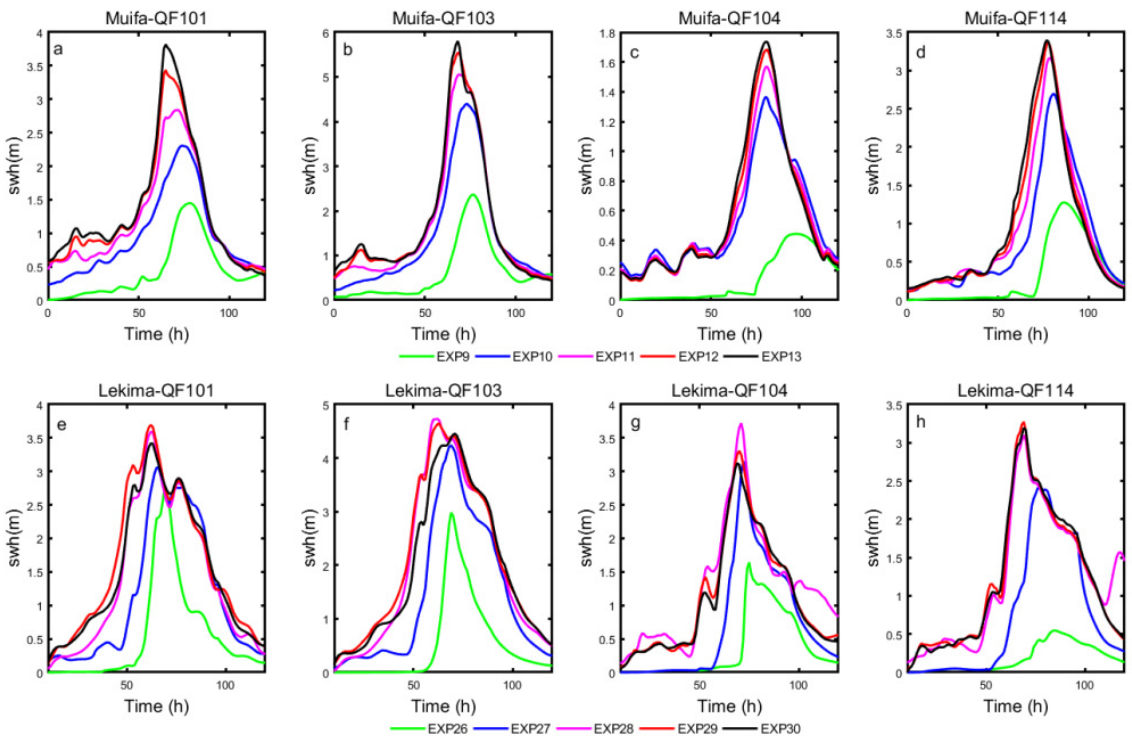

Figure 12. Significant wave height associated with RMW over time at (a) QF101, (b) QF103, (c) QF104, and (d) QF114 for Typhoon Muifa and (e) QF101, (f) QF103, (g) QF104, and (h) QF114 for Typhoon Lekima.

A typhoon's RMW not only affects the wave height but also influences the storm surge. From the spatial distribution of the storm surge of Typhoon Muifa shown in Figure 13, it is clear that Haizhou Bay and Gyeonggiman were strongly influenced during the entire duration of the typhoon. The storm surge in these two areas became stronger as the RMW grew larger. Over time, the maximum storm surge had a positive correlation with the typhoon RMW. When the RMW was less than $10 \mathrm{~km}$, the storm surge at all stations was barely influenced. When the typhoon RMW was greater than $10 \mathrm{~km}$, the line of the storm surge plotted in Figure 14 had a similar variation trend. This is because the path of Typhoon Muifa passed through the Northern Yellow Sea. When the typhoon's RMW was less than $20 \mathrm{~km}$, the area influenced was too small to affect Shandong Peninsula. However, as the typhoon's RMW grew larger, the observation stations recorded higher wind velocities, which led to a higher storm surge.
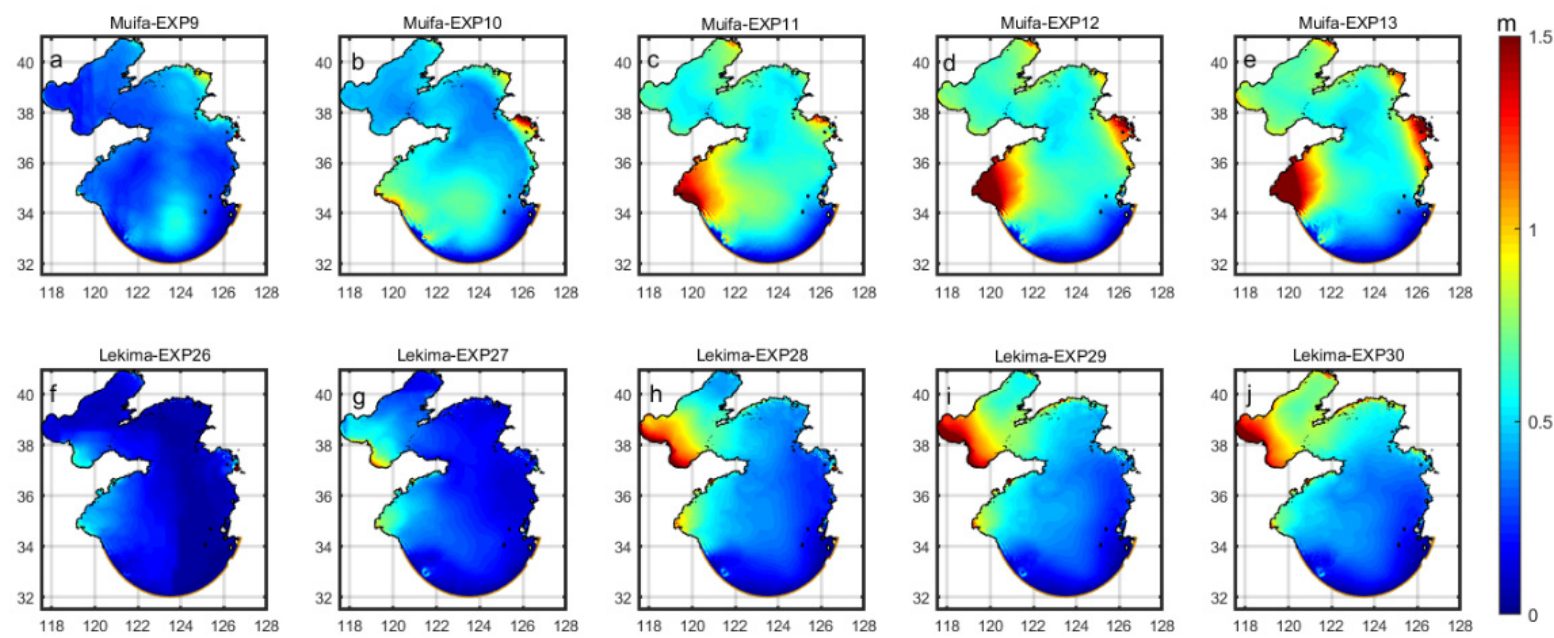

Figure 13. Spatial distribution of the storm surge when the RMW was (a) $10 \mathrm{~km}$, (b) $20 \mathrm{~km}$, (c) $30 \mathrm{~km}$, (d) $40 \mathrm{~km}$, and (e) $50 \mathrm{~km}$ based on Typhoon Muifa and (f) $10 \mathrm{~km},(\mathrm{~g}) 20 \mathrm{~km},(\mathbf{h}) 30 \mathrm{~km}$, (i) $40 \mathrm{~km}$, and (j) $50 \mathrm{~km}$ based on Typhoon Lekima. 

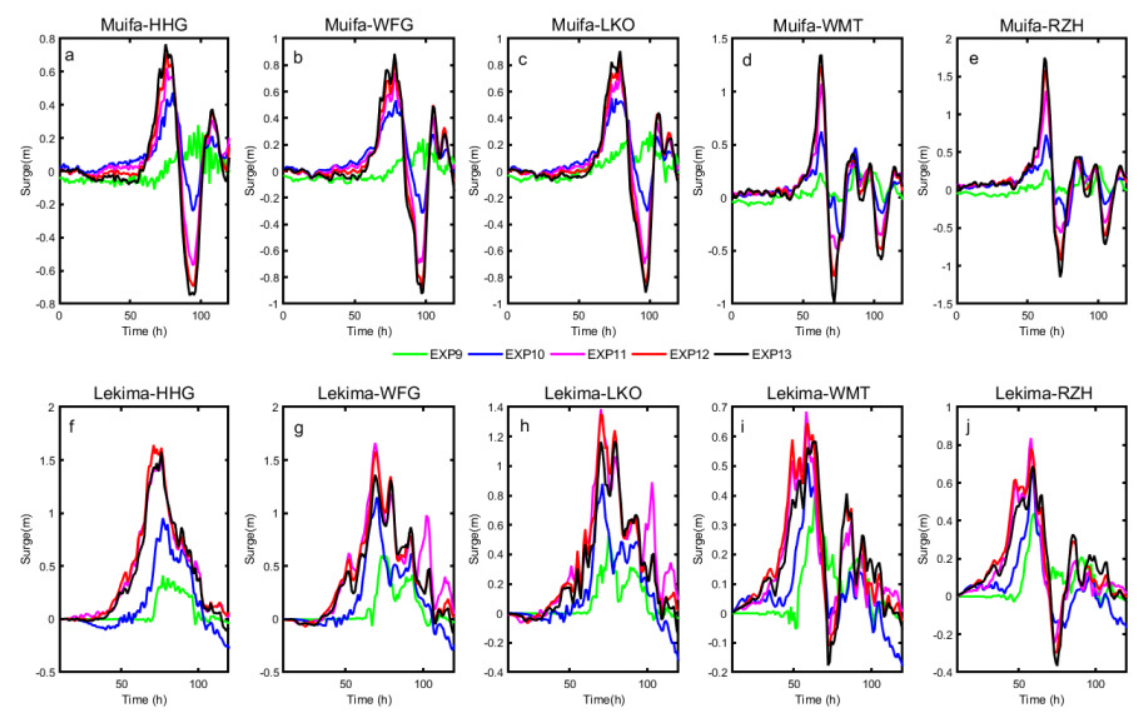

Figure 14. Storm surge associated with the RMW over time at (a) HHG, (b) WFG, (c) LKO, (d) WMT, and (e) RZH for Typhoon Muifa and (f) HHG, (g) WFG, (h) LKO, (i) WMT, and (j) RZH for Typhoon Lekima.

In the case of Typhoon Lekima, the spatial distribution of the storm surge in Figure 13 shows that Bohai Bay and Laizhou Bay were the areas most influenced over the entire duration of the typhoon. The storm surge in these two areas became larger and stronger as the maximum wind speed grew higher. At five stations, the results of the storm surge simulations did not show an increasing pattern as the results for Typhoon Muifa did. This was because the path of Typhoon Lekima passed over Shandong Peninsula, and the stations there were sensitive to the change in the wind field. However, the maximum value of the storm surge occurred in experiment 28. This conclusion confirmed the same pattern that occurred in the simulations of the significant wave height.

\subsection{Translation Speed}

The speed of a typhoon's forward motion (translation speed) is another factor that could influence the typhoon intensity. Rego [71] showed that a hurricane's forward speed is a significant parameter that has been overlooked in previous studies. A previous study of the Northern East China Sea also focused a little on the typhoon translation speed. From Figure 15, it is clear that the spatial distribution of the significant wave height was nearly the same in EXP14 and EXP15. When the typhoon's speed was $30 \mathrm{~km} / \mathrm{h}$, the magnitude of the significant wave height in the Northern Yellow Sea decreased. As shown in Figure 16, other buoys showed a similar change pattern. The slower the typhoon's speed, the longer the duration of s high significant wave height and the later the highest wave height occurred.

In the case of Typhoon Lekima, a slower typhoon speed led to a larger significant wave height. The spatial distribution of the significant wave height was nearly the same in EXP31 and EXP21. When the typhoon speed was $30 \mathrm{~km} / \mathrm{h}$, the significant wave height in Bohai and north of the Yellow Sea decreased dramatically. Other buoys showed a pattern similar to that seen with Typhoon Muifa.

The typhoon translation speed was one of the most important factors influencing the storm surge. In diagrams of the spatial distribution of the storm surge during Typhoon Muifa (Figure 17), the area affected by the storm surge in Haizhou Bay, Bohai Bay, and Laizhou Bay showed a strong negative correlation with the typhoon translation speed. The maximum value of the storm surge in Korea Bay and Gyeonggiman decreased when the typhoon speed increased. The area affected by the storm surge did not show a negative correlation with the typhoon speed. In Liaodong Bay, the maximum value of the storm surge and influenced area increased while the typhoon speed increased. 

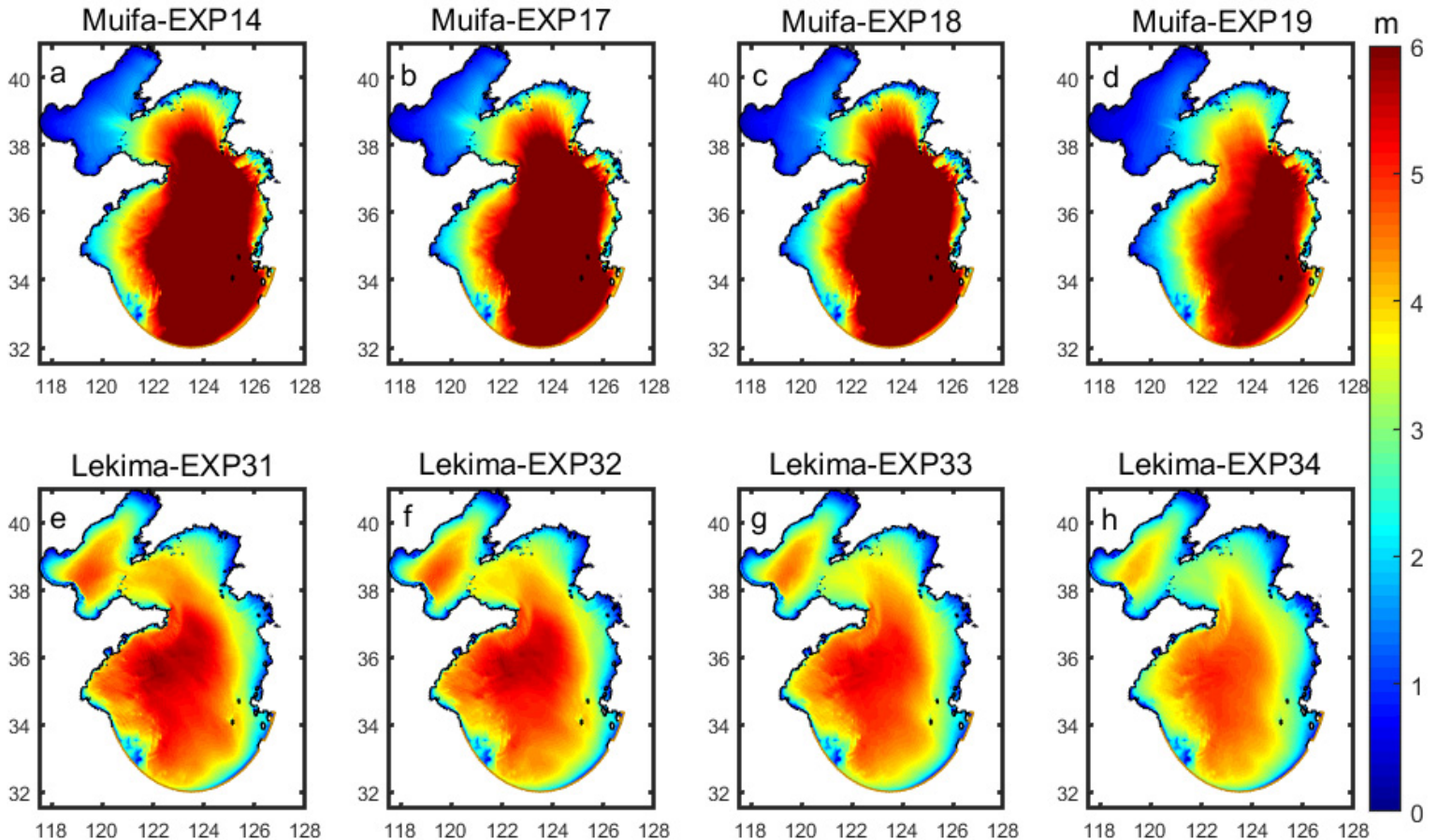

Figure 15. Spatial distribution of a significant wave height when the translation speed was (a) $7.5 \mathrm{~km} / \mathrm{h},(\mathbf{b}) 15 \mathrm{~km} / \mathrm{h}$, (c) $30 \mathrm{~km} / \mathrm{h}$, and (d) $60 \mathrm{~km} / \mathrm{h}$ based on Typhoon Muifa and (e) $7.5 \mathrm{~km} / \mathrm{h}$,

(f) $15 \mathrm{~km} / \mathrm{h},(\mathrm{g}) 30 \mathrm{~km} / \mathrm{h}$, and (h) $60 \mathrm{~km} / \mathrm{h}$ based on Typhoon Lekima.
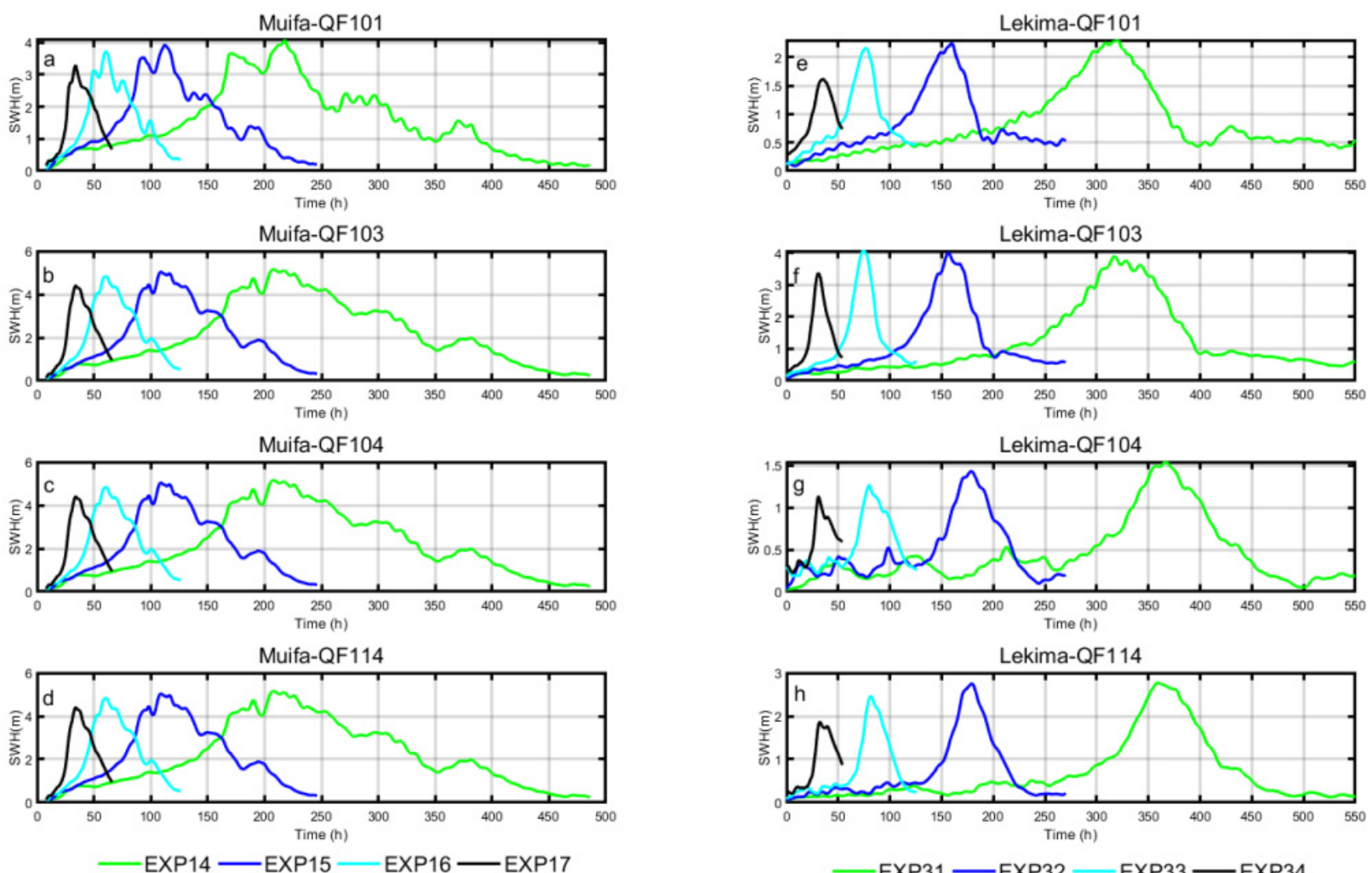

Figure 16. Significant wave height associated with the translation speed over time at (a) QF101, (b) QF103, (c) QF104, and (d) QF114 for Typhoon Muifa and (e) QF101, (f) QF103, (g) QF104, and (h) QF114 for Typhoon Lekima. 

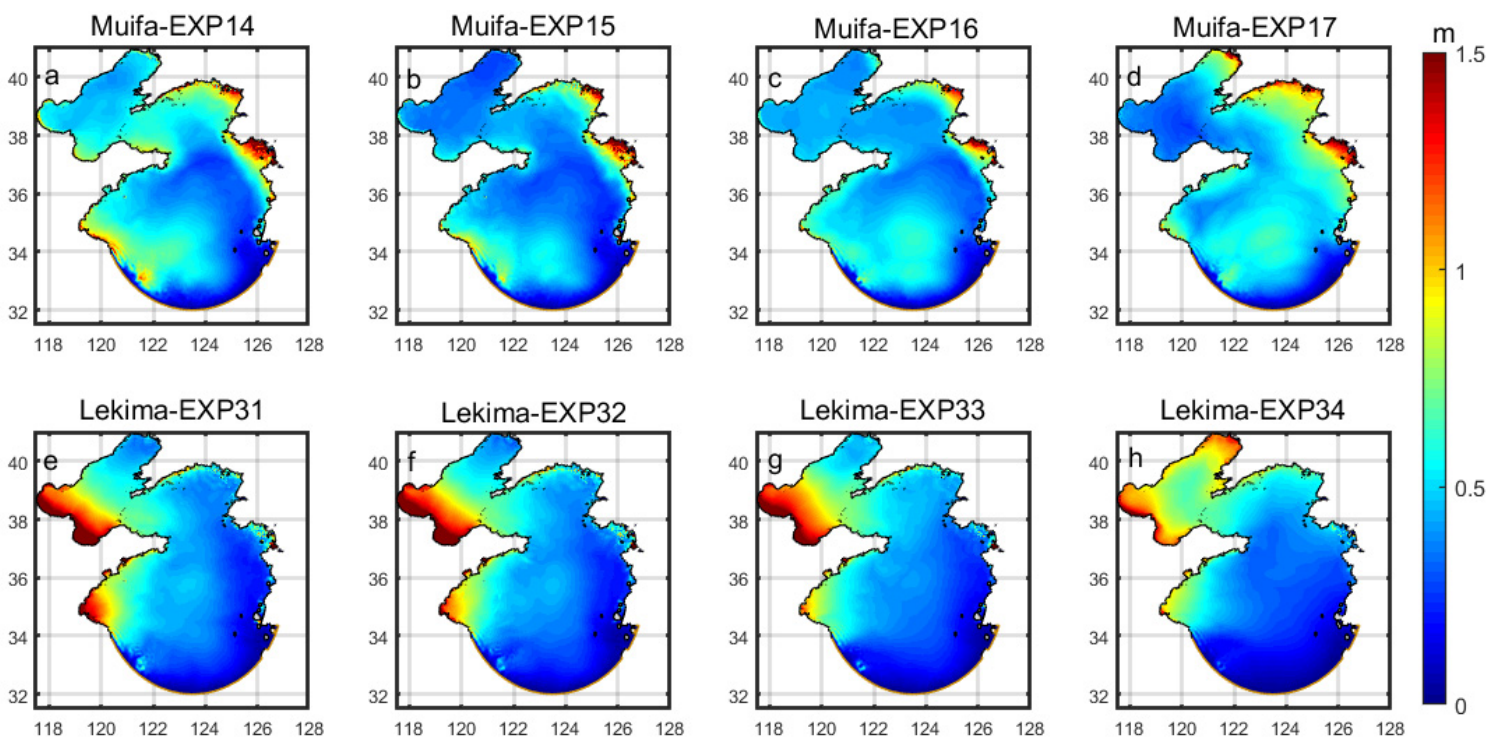

Figure 17. Spatial distribution of the storm surge when the translation speed was (a) $7.5 \mathrm{~km} / \mathrm{h}$, (b) $15 \mathrm{~km} / \mathrm{h}$, (c) $30 \mathrm{~km} / \mathrm{h}$, and (d) $60 \mathrm{~km} / \mathrm{h}$ based on Typhoon Muifa and (e) $7.5 \mathrm{~km} / \mathrm{h}$, (f) $15 \mathrm{~km} / \mathrm{h}$, (g) $30 \mathrm{~km} / \mathrm{h}$, and (h) $60 \mathrm{~km} / \mathrm{h}$ based on Typhoon Lekima.

In the case of Typhoon Lekima, a faster typhoon translation speed was associated with a decrease in the maximum value of the storm surge in the areas affected in Haizhou Bay, Bohai Bay, and Laizhou Bay. However, in Liaodong Bay, the maximum value of the storm surge and the area influenced both increased. The reasons for this were as same as for the simulations of Typhoon Muifa. Figure 18 shows that a slower typhoon speed led to a higher maximum value of the storm surge, later occurrence of the highest value, and longer duration.

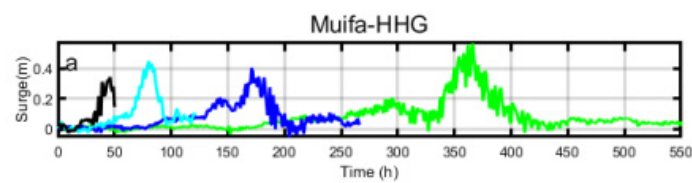

Muifa-WFG
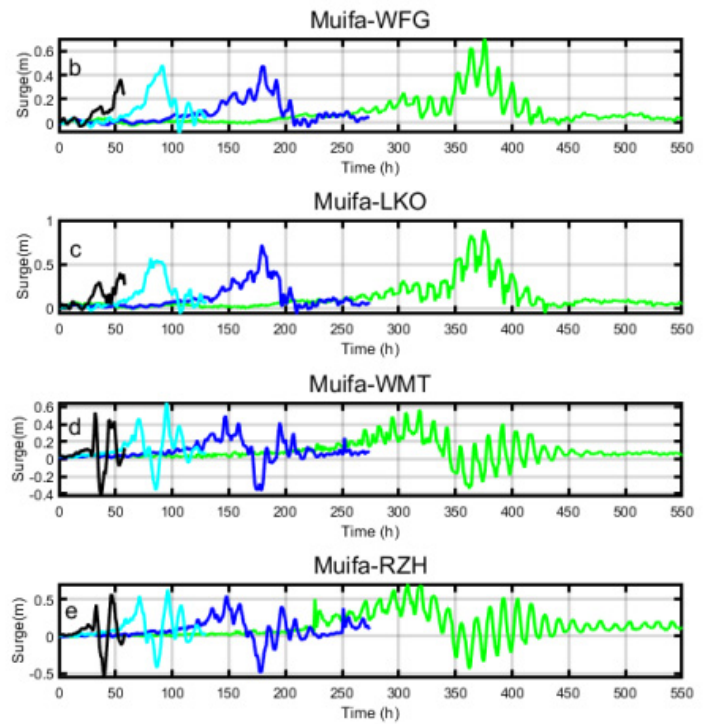

$-\operatorname{EXP14} \longrightarrow \operatorname{EXP15}-\operatorname{EXP16}-\operatorname{EXP17}$
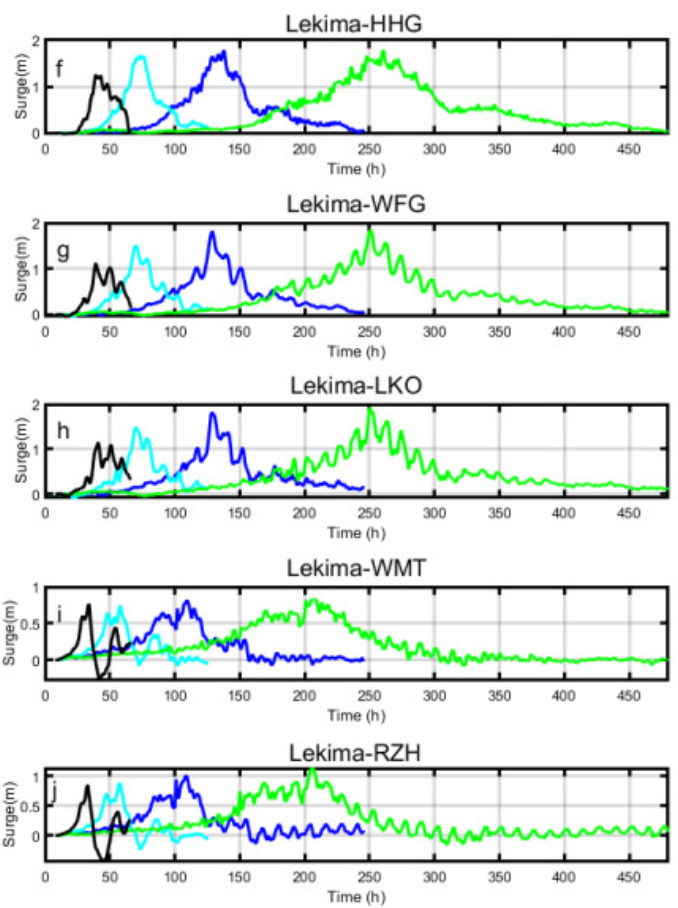

$-\operatorname{EXP31}-\operatorname{EXP} 32-\operatorname{EXP} 33-\operatorname{EXP34}$

Figure 18. Storm surge associated with the translation speed over time at (a) HHG, (b) WFG, (c) LKO, (d) WMT, and (e) RZH for Typhoon Muifa and (f) HHG, (g) WFG, (h) LKO, (i) WMT, and (j) RZH for Typhoon Lekima. 


\section{Discussion}

\subsection{The Impacts of Typhoon Parameters on Significant Wave Height}

The plotting lines of the maximum significant wave height on the same buoys show the trends when one typhoon parameter was changed. In Figure 19a, all of the lines are close to linear in the simulations with a changing maximum wind speed in the case of Typhoon Muifa. Different buoys had large differences in the slope. In the case of Typhoon Lekima, the lines drawn based on data at different buoys showed a similar slope. Li [15] obtained the same results in the South China Sea during Super-typhoon Hato (2017).
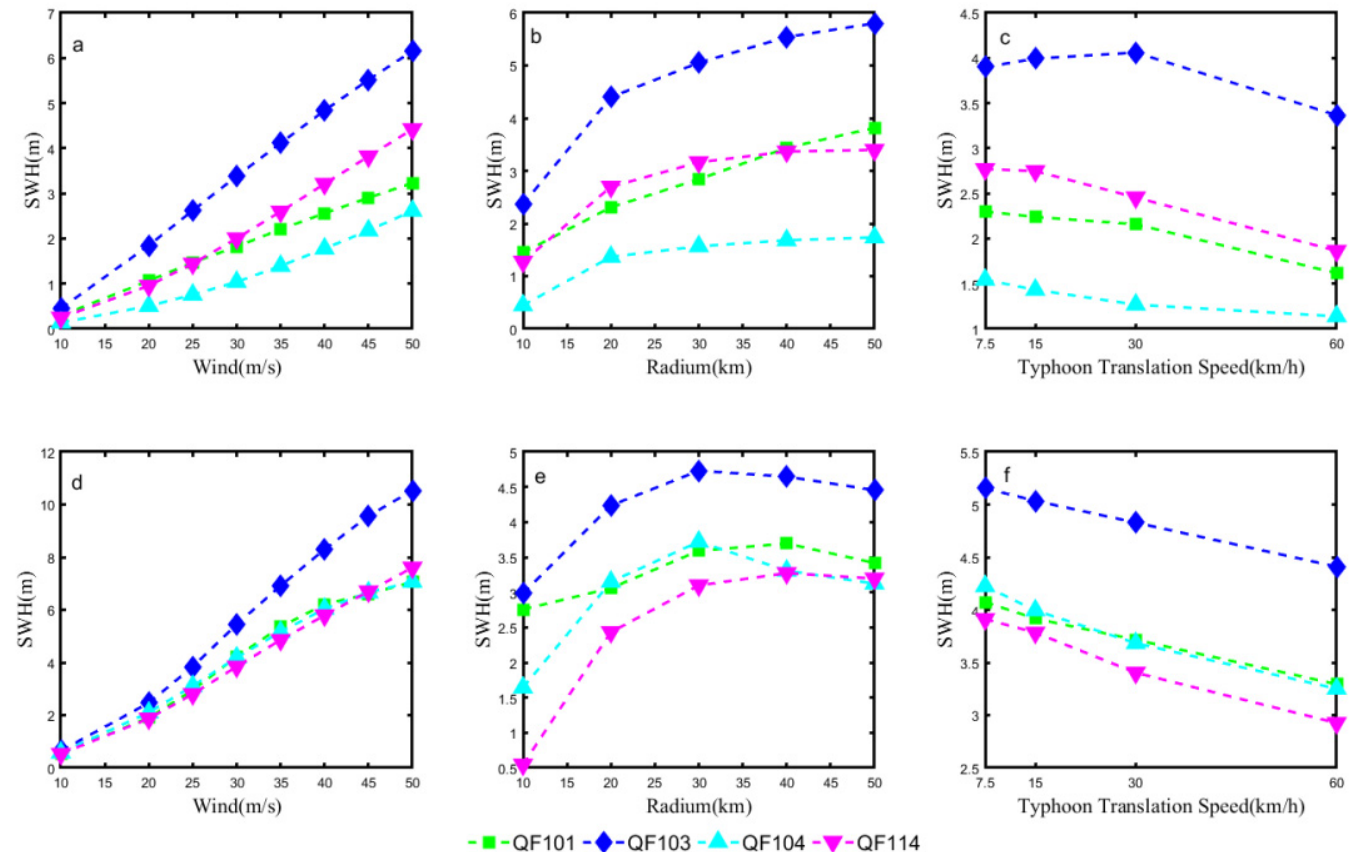

Figure 19. Variation in the maximum value of the significant wave height with (a-d) the maximum wind speed, (b-e) typhoon radius, and (c-f) typhoon translation speed for Typhoon Muifa/Lekima.

Figure 19b,e show plots of the relationship between the maximum value of the significant wave height and typhoon radius. In Figure 19b, different lines in different buoys were all monotonously increasing and had a slowing growth trend. Since the center of Typhoon Lekima passed over Shandong Peninsula, the maximum significant wave height increased initially and then decreased.

Figure 19c,f show the relationship between the maximum value of significant wave height and typhoon speed. In the typhoon speed experiments, it was clear that the maximum significant wave height decreased in a nearly linear trend while the typhoon speed increased several times over.

\subsection{The Impact of Typhoon Parameters on Storm Surge}

An extreme disaster was caused not only by maximum value but, also, lasting-time during the typhoon process. Previous studies usually studied the maximum to measure the potential damages $[15,63]$. However, one single evaluation indicator may not evaluate the potential damages comprehensively. Therefore, a time accumulative effect of the storm surge was calculated as the Intensity Index in this study, which can be calculated from the equation below:

$$
\mathcal{I}=\int_{0}^{\mathrm{t}} \mathrm{f}(\mathrm{t}) \mathrm{dt},
$$

where $f(t)$ is the storm surge in time series. This Intensity Index not only considers the height of a storm surge but also the time effect of typhoon impacts. Therefore, using Equation (16) was reasonable in this study. 
Previous studies used systematic numerical experiments carried out in an idealized continental shelf-beach-land system to identify the role of waves in modeling storm surges. $\mathrm{Wu}$ [63] showed that the maximum storm surge increases almost linearly as the hurricane maximum wind speed increases. In order to explore the relationship between maximum wind speed and maximum storm surge, these two variables were plotted in Figure 20. In Figure 20a, simulations of the maximum storm surge and maximum wind speed are drawn as a broken line. It can be seen that all of the lines increase steadily. In the case of Typhoon Lekima, all the stations showed a positive, nearly liner relationship between the maximum wind speed and maximum storm surge. Due to their proximity to one another, the curves for the maximum storm surge at stations HHG, WFG, and LKO had the same variation pattern. The curves for the maximum storm surge at stations WMT and RZH had the same variation pattern. Figure 20d,j show that the intensity of Typhoon Muifa and Typhoon Lekima both had a positive relationship with the maximum wind speed. On Path 1, different stations show similar variation patterns with respect to the intensity of the storm surge. However, the results show that the intensity had a strong relationship with the location of Typhoon Lekima. Stations HHG, WFG, and LKO were located in Bohai Sea, which means the lines of these stations had faster growth rates than those of stations WMT and $\mathrm{RZH}$, which were located in the Yellow Sea. These results also verified the experiments designed by $\mathrm{Wu}[63]$.
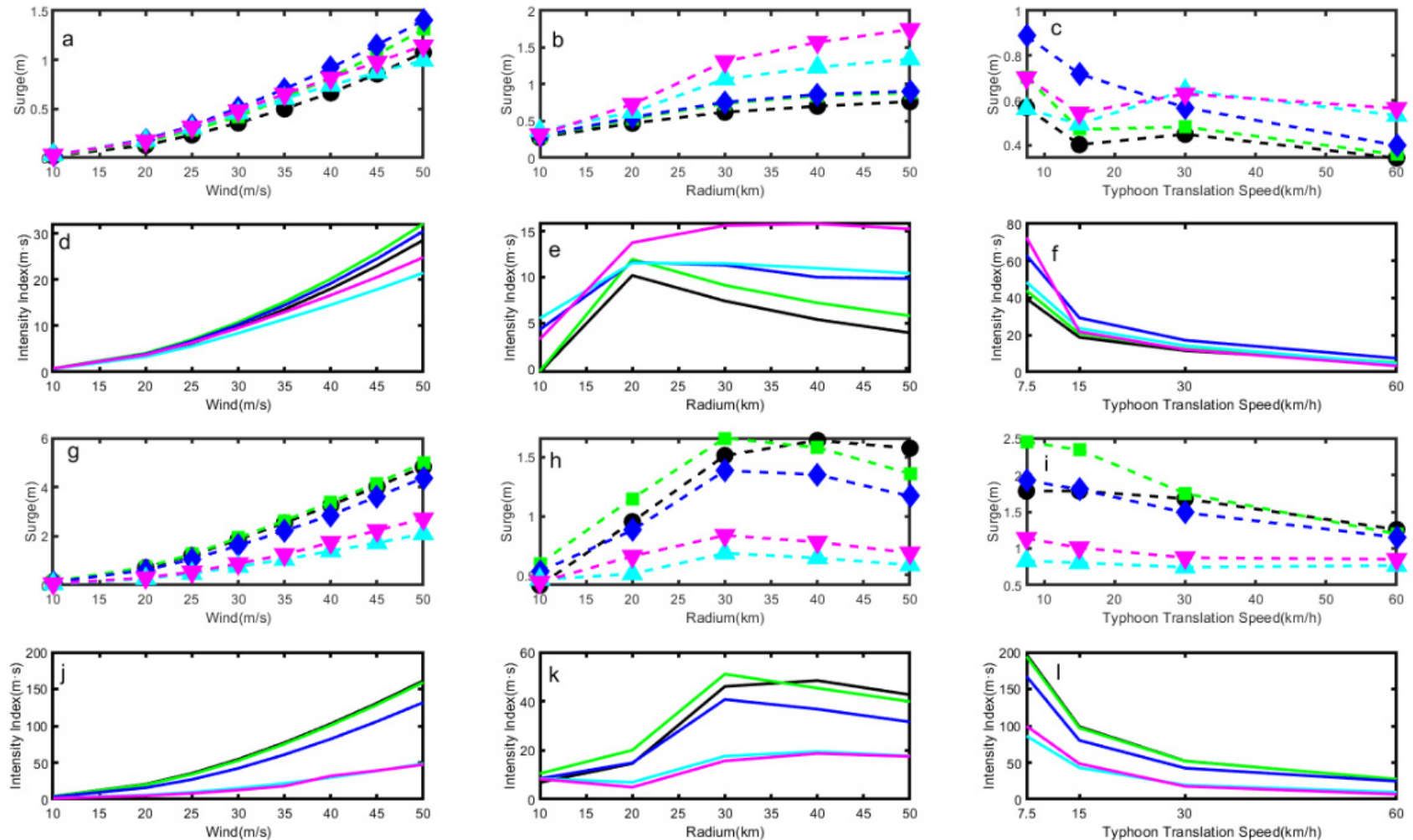

$-\mathrm{HHG}-\mathbf{m}-\mathrm{WFG}-\boldsymbol{-}-\mathrm{LKO}-\mathbf{A}-\mathrm{WMT}-\boldsymbol{\nabla}-\mathrm{RZH}$

$-\mathrm{HHG}-\mathrm{WFG}-\mathrm{LKO}-\mathrm{WMT} \longrightarrow \mathrm{RZH}$

Figure 20. Variation in the maximum value of the storm surge (Intensity Index) with the (a-d) maximum wind speed, (b-e) typhoon radius, and (c-f) typhoon translation speed for Typhoon Muifa. Variation in the maximum value of the storm surge (Intensity Index) with the (g-i) maximum wind speed, (h-k) typhoon radius, and (i-l) typhoon translation speed for Typhoon Lekima.

Figure $20 \mathrm{~b}$ and $\mathrm{h}$ show the relationship between the typhoon radius and corresponding maximum storm surge. The maximum storm surge showed a positive correlation with the typhoon radius for Typhoon Muifa. However, the rate of increase declined as the typhoon radius became larger. The maximum storm surge over the duration of Typhoon Lekima had 
an extreme value. At station HHG, the maximum value occurred when the abscissa was $40 \mathrm{~km}$. At stations WFG, LKO, WMT, and RZH, the maximum value occurred when the typhoon radius was $30 \mathrm{~km}$. This difference was because the typhoon paths were different. Typhoon Muifa passed through the Yellow Sea and made landfall at Korea Bay. Typhoon Lekima passed over Shandong Peninsula. The radius of the maximum wind speed of Typhoon Lekima could surround Shandong Peninsula, while that of Typhoon Muifa could not. Due to their geographic positions, different stations showed different change rules. As shown in Figure 20e, stations RZH and WMT are located in the Yellow Sea. At station RZH, the intensity of Typhoon Muifa increased, while the typhoon radius expanded. At station WMT, the intensity of Typhoon Muifa increased initially and remained nearly unchanged. At other stations, where the typhoon radius and corresponding maximum storm surge had a strong positive correlation, the intensity increased initially and ultimately decreased. This is because the air pressure gradient force decreased, and the minimum storm surge decreased. The overall result showed a decreasing intensity. The intensity showed a strong correlation with the maximum storm surge in Typhoon Lekima. The pressure field of Typhoon Lekima did not have a negative influence on the typhoon progress.

Figure 20c,i show the relationship between the maximum value of the storm surge and typhoon speed. It can be seen that, despite the twists and turns in the middle because of the topography, overall, the maximum value of the storm surge and typhoon speed showed a slight negative correlation at station HHG. Therefore, a faster typhoon speed led to a lower storm surge. The intensity calculated from Equation (16) was plotted in Figure 20f,1. As the typhoon speed increased, the intensity of the typhoon declined dramatically at all the stations. During the progress of Typhoon Muifa, the variation tendency first decreased rapidly and then tended to be stable. Figure 20f,l show an exponential decrease in typhoon speed and storm surge during Typhoon Lekima.

\subsection{A Comparative Study of Typhoons Muifa and Typhoon Lekima}

Figure 21a plots a linear fitting curve with the maximum wind speed and maximum value of the significant wave data from all buoys. The slope of the lines was 0.09713 for Typhoon Muifa and 0.1978 for Typhoon Lekima, which indicates that the amplitude of the typhoon that made landfall on Shandong Peninsula was greater than that of the typhoon that did not make landfall on Shandong Peninsula. Figure 21d shows a linear fitting curve calculated from the maximum value of the storm surge data from all the buoys. The slope of the line was 0.0299 for Typhoon Muifa and 0.0957 for Typhoon Lekima. Therefore, the increase in the amplitude of Typhoon Muifa was greater than that of Typhoon Lekima. The same pattern was seen for the significant wave height. Figure $21 \mathrm{~g}$ shows a linear fitting curve calculated based on the Intensity Index of the significant wave data from all the buoys. The slope of the line was 0.6844 for Typhoon Muifa and 2.744 for Typhoon Lekima, which could indicate that the Intensity Index of the storm surge for the typhoon that made landfall on Shandong Peninsula was more sensitive than that of the typhoon that did not make landfall on Shandong Peninsula.

Comparing the variation pattern of the RMW with the significant wave height for Typhoon Muifa and Typhoon Lekima in Figure 21b, it can be seen that the maximum value of the significant wave height increased initially and then decreased. It was because the radius of the typhoon maximum velocity expanded. However, the maximum value of the significant wave height continued to increase during Typhoon Muifa, because Typhoon Muifa crossed the Yellow Sea, and the maximum wind speed did not reach Shandong Peninsula. Figure 21e,h show the variation patterns of Typhoon Muifa and Typhoon Lekima with respect to the maximum storm surge and the Intensity Index. The maximum storm surge increased initially and decreased afterwards as the RMW grew larger. The Intensity Index of Typhoon Lekima had the same pattern as the RMW, because they had the same significant wave height. Since Typhoon Muifa made landfall far from Shandong Peninsula, the maximum storm surge was larger when the RMW was larger. The Intensity Index of Typhoon Muifa increasing initially and remained unchanged. 

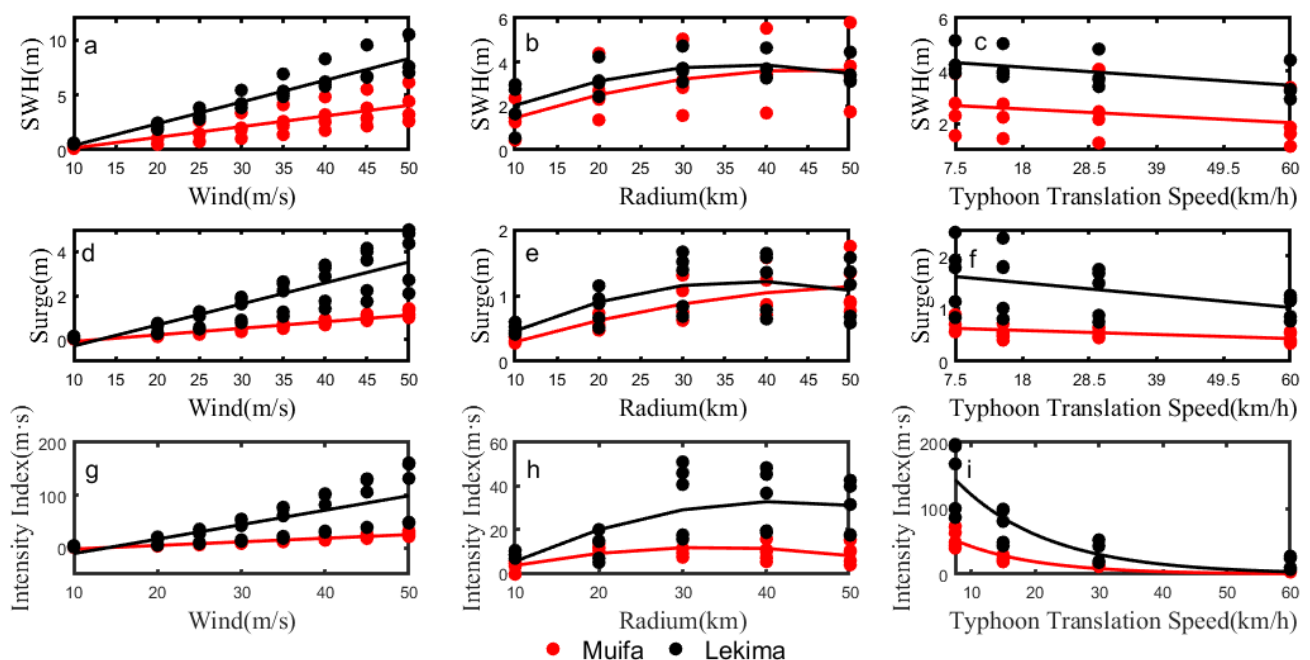

Figure 21. Fitted curve between the maximum significant wave height and (a) maximum wind speed; (b) radius of the maximum wind speed; (c) typhoon translation speed, maximum storm surge, and (d) maximum wind speed; (e) radius of the maximum wind speed; (f) typhoon translation speed; the Intensity Index of the maximum storm surge; and the (g) maximum wind speed, (h) radius of maximum wind speed, and (i) typhoon translation speed.

Figure 21c shows the variation patterns of the maximum significant wave height of Typhoon Muifa and Typhoon Lekima. As the typhoon's movement speed increased, the maximum significant wave height decreased by less than one meter. Though Typhoon Muifa and Typhoon Lekima had different paths, they had the same variation patterns. The linear line of the storm surge in Figure $21 \mathrm{f}$ was calculated using the linear fitting least squares method to compare the patterns of Typhoon Muifa and Typhoon Lekima. The slope coefficient of the linear line for Typhoon Muifa was 0.02074, and for Typhoon Lekima, it was 0.05583. Compared to Typhoon Muifa, Typhoon Lekima was much more sensitive to the typhoon movement speed. With respect to the Intensity Index, Typhoon Muifa and Typhoon Lekima both showed an exponential decrease between the intensity and typhoon translation speed. When the typhoon translation speed was $7.5 \mathrm{~km} / \mathrm{h}$, the Intensity Index of Typhoon Lekima was much higher than that of Typhoon Muifa. When the typhoon translation speed increased, the Intensity Index of Typhoon Lekima decreased more rapidly than Typhoon Lekima and tended to have the same Intensity Index.

\subsection{Resonance of the Storm Surge}

In diagrams of the spatial distribution of storm surge (Figure 17), the area affected by the storm surge increased in Liaodong Bay when the typhoon translation speed increased. This is because an abnormal sea level rise will occur when an external disturbance moves into a bay and meets certain conditions [72,73]. According to Equation (17), it can be calculated that

$$
\begin{gathered}
\frac{\partial \mathrm{u}}{\partial \mathrm{t}}+\mathrm{g} \frac{\partial \eta}{\partial \mathrm{x}}=-\frac{1}{\rho} \frac{\partial \mathrm{P}_{\mathrm{a}}}{\partial \mathrm{x}}+\frac{\tau_{\mathrm{a}}}{\rho \mathrm{h}^{\prime}}, \\
\frac{\partial^{2} \eta}{\partial \mathrm{t}^{2}}=\mathrm{gH} \frac{\partial^{2}(\eta-\tilde{\eta})}{\partial \mathrm{x}^{2}},
\end{gathered}
$$

where $\tilde{\eta}=\frac{P_{\infty}-P_{a}}{\rho g}$, and $P_{a}=P_{\infty}-\rho g \tilde{\eta}$.

If $\mathrm{V}$ is the typhoon translation speed, then

$$
\eta=\eta(\xi), \tilde{\eta}=\tilde{\eta}(\xi), \xi=x-V t \text { and } V^{2} \frac{\partial^{2} \eta}{\partial \xi^{2}}=g H \frac{\partial^{2}(\eta-\tilde{\eta})}{\partial \xi^{2}} \text {. }
$$


Finally, the storm surge level can be calculated as below:

$$
\eta=\frac{\tilde{\eta}}{1-\left(\frac{\mathrm{v}}{\mathrm{C}_{0}}\right)}
$$

where $\mathrm{C}_{0}^{2}=\mathrm{gH}, \eta$ is the sea level, and $\mathrm{v}$ is the typhoon translation speed.

The sea level will elevate abnormally when the typhoon translation speed is close to $\mathrm{C}_{0}$, which is also called the storm surge resonance phenomenon. In this study, the maximum translation speed was $60 \mathrm{~km} / \mathrm{h} . \mathrm{C}_{0}^{2}=\mathrm{gH}$ in the Bohai Sea and Northern Yellow Sea was between $47 \mathrm{~km} / \mathrm{h}$ and $60 \mathrm{~km} / \mathrm{h}$ (calculated from the mean depth of the Bohai Sea and the Yellow Sea). Therefore, in experiments 14-17 and 31-34, the maximum surge level increased rapidly along the Coasts of Liaodong Bay and Korea Bay. At Bohai Bay and Laizhou Bay, the typhoon translation speed accelerated, the integral of the wind stress with respect to time decreased, and the surge height showed a negative relationship with the typhoon translation speed.

\section{Conclusions}

This study chose the maximum wind speed, typhoon radius, and typhoon translation speed to calculate a typhoon intensity impact index. Forty experiments were designed, and the model results verified that using the SWAN + ADCIRC model for this task was reasonable.

In the maximum wind speed experiments, significant wave height results showed that the area influenced by the typhoon was larger when the maximum wind speed was higher. Furthermore, the maximum wind speed had a linear positive correlation with the maximum significant wave height. With respect to the storm surge, when the typhoon maximum wind speed was higher, the area affected by the typhoon was larger. The maximum storm surge and Intensity Index both had a near-linear positive correlation to the maximum typhoon wind speed.

In the typhoon radius experiments, both significant wave height results showed that the area influenced by the typhoon was larger when the typhoon radius was larger. The maximum significant wave height had a strong positive correlation with the radius when the typhoon radius was less than $20 \mathrm{~km}$ in the case of Typhoon Muifa. When the typhoon radius was larger than $20 \mathrm{~km}$, the maximum significant wave height showed a slowing growth trend. In the case of Typhoon Lekima, the maximum significant wave height had a strong positive correlation with the radius when the typhoon's radius was less than $30 \mathrm{~km}$. When the typhoon's radius was larger than $30 \mathrm{~km}$, the maximum significant wave height showed a sluggish growth trend and even may have had a decreasing tendency. With respect to the storm surge, the results from both typhoons showed that the area influenced was larger when the typhoon radius was larger. In the case of Typhoon Muifa, the maximum storm surge increased in a nearly linear pattern when the typhoon radius expanded. The Intensity Index increased initially and then decreased when the typhoon radius was greater than $20 \mathrm{~km}$. In the case of Typhoon Lekima, the maximum storm surge increased in a nearly linear pattern when the typhoon radius was smaller than $30 \mathrm{~km}$. When the typhoon radius was larger than $30 \mathrm{~km}$, the maximum storm surge decreased, because the typhoon wind field first increased then decreased from the typhoon center to the periphery. The Intensity Index had a similar pattern.

In the typhoon translation speed experiments, a fast translation speed triggered a storm surge resonance. The significant wave height on both paths showed that the area influenced by the typhoon was smaller when the typhoon was moving faster. The experiments with Typhoon Muifa and Typhoon Lekima showed a similar pattern in the significant wave heights and storm surges. When the typhoon translation speed was faster, the duration of the high significant wave height was longer. The maximum significant wave height did not change much with the typhoon translation speed. The Intensity Index decreased exponentially when the typhoon translation speed was rapid. 


\begin{abstract}
Author Contributions: Conceptualization, J.W. and D.M.; Data curation, J.L.; Formal analysis, J.W.; Funding acquisition, Y.H.; Investigation, J.W.; Methodology, J.W.; Project administration, Y.H.; Resources, Y.H.; Software, J.W.; Supervision, Y.H., B.Y. and D.M.; Validation, D.M.; Visualization, J.W., D.M., S.L. and M.D.; Writing-original draft, J.W.; and Writing-review and editing, D.M. All authors have read and agreed to the published version of the manuscript.
\end{abstract}

Funding: This study was jointly funded by the National Natural Science Foundation of China, grant numbers U1706216, 42006027, and U1806227; the Strategic Priority Research Program of the Chinese Academy of Sciences, grant number XDA19060202; and the Key Deployment Project of Center for Ocean Mega-Science, Chinese Academy of Sciences, grant number COMS2019J02.

Institutional Review Board Statement: Not applicable.

Informed Consent Statement: Not applicable.

Data Availability Statement: The data presented in this study are available on request from the corresponding author.

Acknowledgments: The authors are grateful to the North China Sea Marine Forecasting Centre, Ministry of Natural Resources for providing the observational data and assisting in the model verification.

Conflicts of Interest: The authors declare no conflict of interest.

\title{
References
}

1. Chan, J.C.L.; Shi, J.-E. Long-term trends and interannual variability in tropical cyclone activity over the western North Pacific. Geophys. Res. Lett. 1996, 23, 2765-2767. [CrossRef]

2. You, S.H.; Seo, J.-W. Storm surge prediction using an artificial neural network model and cluster analysis. Nat. Hazards 2009, 51, 97-114. [CrossRef]

3. Yang, Z.; Wang, T.; Leung, R.; Hibbard, K.; Janetos, T.; Kraucunas, I.; Rice, J.; Preston, B.; Wilbanks, T. A modeling study of coastal inundation induced by storm surge, sea-level rise, and subsidence in the Gulf of Mexico. Nat. Hazards 2013, 71, 1771-1794. [CrossRef]

4. Xu, J.; Zhang, Y.; Cao, A.; Liu, Q.; Lv, X. Effects of tide-surge interactions on storm surges along the coast of the Bohai Sea, Yellow Sea, and East China Sea. Sci. China Earth Sci. 2016, 59, 1308-1316. [CrossRef]

5. Andrade, C.A.; Thomas, Y.F.; Lerma, A.N.; Durand, P.; Anselme, B. Coastal Flooding Hazard Related to Swell Events in Cartagena de Indias, Colombia. J. Coast. Res. 2013, 290, 1126-1136. [CrossRef]

6. Wang, H.; Loftis, J.; Liu, Z.; Forrest, D.; Zhang, J. The Storm Surge and Sub-Grid Inundation Modeling in New York City during Hurricane Sandy. J. Mar. Sci. Eng. 2014, 2, 226-246. [CrossRef]

7. Yin, J.; Lin, N.; Yu, D. Coupled modeling of storm surge and coastal inundation: A case study in New York City during Hurricane Sandy. Water Resour. Res. 2016, 52, 8685-8699. [CrossRef]

8. Sheng, Y.P.; Zhang, Y.; Paramygin, V.A. Simulation of storm surge, wave, and coastal inundation in the Northeastern Gulf of Mexico region during Hurricane Ivan in 2004. Ocean. Model. 2010, 35, 314-331. [CrossRef]

9. Bilskie, M.V.; Hagen, S.C.; Medeiros, S.C.; Cox, A.T.; Salisbury, M.; Coggin, D. Data and numerical analysis of astronomic tides, wind-waves, and hurricane storm surge along the northern Gulf of Mexico. J. Geophys. Res. Ocean. 2016, 121, 3625-3658. [CrossRef]

10. Bhaskaran, P.K.; Gayathri, R.; Murty, P.L.N.; Bonthu, S.; Sen, D. A numerical study of coastal inundation and its validation for Thane cyclone in the Bay of Bengal. Coast. Eng. 2014, 83, 108-118. [CrossRef]

11. Bhaskaran, P.K.; Nayak, S.; Bonthu, S.R.; Murty, P.L.N.; Sen, D. Performance and validation of a coupled parallel ADCIRC-SWAN model for THANE cyclone in the Bay of Bengal. Environ. Fluid Mech. 2013, 13, 601-623. [CrossRef]

12. Gayathri, R.; Bhaskaran, P.K.; Sen, D. Numerical Study on Storm Surge and Associated Coastal Inundation for 2009 AILA Cyclone in the Head Bay of Bengal. Aquat. Procedia 2015, 4, 404-411. [CrossRef]

13. Du, M.; Hou, Y.; Hu, P.; Wang, K. Effects of Typhoon Paths on Storm Surge and Coastal Inundation in the Pearl River Estuary, China. Remote Sens. 2020, 12, 1851. [CrossRef]

14. Yin, K.; Xu, S.; Huang, W.; Xie, Y. Effects of sea level rise and typhoon intensity on storm surge and waves in Pearl River Estuary. Ocean. Eng. 2017, 136, 80-93. [CrossRef]

15. Li, A.; Guan, S.; Mo, D.; Hou, Y.; Hong, X.; Liu, Z. Modeling wave effects on storm surge from different typhoon intensities and sizes in the South China Sea. Estuar. Coast. Shelf Sci. 2020, 235, 106551. [CrossRef]

16. Wang, K.; Hou, Y.; Li, S.; Du, M.; Li, R. Numerical Study of Storm Surge Inundation in the Southwestern Hangzhou Bay Region During Typhoon Chan-Hom in 2015. J. Ocean Univ. China 2020, 19, 263-271. [CrossRef]

17. Du, M.; Hou, Y.; Qi, P.; Wang, K. The impact of different historical typhoon tracks on storm surge: A case study of Zhejiang, China. J. Mar. Syst. 2020, 206, 103318. [CrossRef] 
18. Yin, J.; Yin, Z.-E.; Hu, X.-M.; Xu, S.-Y.; Wang, J.; Li, Z.-H.; Zhong, H.-D.; Gan, F.-B. Multiple scenario analyses forecasting the confounding impacts of sea level rise and tides from storm induced coastal flooding in the city of Shanghai, China. Environ. Earth Sci. 2010, 63, 407-414. [CrossRef]

19. Pan, Z.-h.; Liu, H. Extreme storm surge induced coastal inundation in Yangtze Estuary regions. J. Hydrodyn. 2019, 31, 1127-1138. [CrossRef]

20. Chang, T.Y.; Chen, H.E.; Hsiao, S.C.; Wu, H.L.; Chen, W.B. Numerical Analysis of the Effect of Binary Typhoons on Ocean Surface Waves in Waters Surrounding Taiwan. Front. Mar. Sci. 2021, 8, 749185. [CrossRef]

21. Chen, W.B.; Chen, H.; Hsiao, S.C.; Chang, C.H.; Lin, L.Y. Wind forcing effect on hindcasting of typhoon-driven extreme waves. Ocean. Eng. 2019, 188, 106260. [CrossRef]

22. Hsiao, S.C.; Chen, H.; Chen, W.B.; Chang, C.H.; Lin, L.Y. Quantifying the contribution of nonlinear interactions to storm tide simulations during a super typhoon event. Ocean. Eng. 2019, 194, 106661. [CrossRef]

23. Hsiao, S.C.; Chen, H.E.; Wu, H.L.; Chen, W.B.; Chang, C.H.; Guo, W.D.; Chen, Y.M.; Lin, L.Y. Numerical Simulation of Large Wave Heights from Super Typhoon Nepartak (2016) in the Eastern Waters of Taiwan. J. Mar. Sci. Eng. 2020, 8, 217. [CrossRef]

24. Shih, H.J.; Chen, H.; Liang, T.Y.; Fu, H.S.; Chang, C.H.; Chen, W.B.; Su, W.R.; Lin, L.Y. Generating potential risk maps for typhoon-induced waves along the coast of it Taiwan. Ocean. Eng. 2018, 163, 1-14. [CrossRef]

25. Hsiao, S.-C.; Wu, H.-L.; Chen, W.-B.; Guo, W.-D.; Chang, C.-H.; Su, W.-R. Effect of Depth-Induced Breaking on Wind Wave Simulations in Shallow Nearshore Waters off Northern Taiwan during the Passage of Two Super Typhoons. J. Mar. Sci. Eng. 2021, 9, 706. [CrossRef]

26. Feng, X.; Yin, B.; Yang, D. Effect of hurricane paths on storm surge response at Tianjin, China. Estuar. Coast. Shelf Sci. 2012, 106, 58-68. [CrossRef]

27. Pelling, H.E.; Uehara, K.; Green, J.A.M. The impact of rapid coastline changes and sea level rise on the tides in the Bohai Sea, China. J. Geophys. Res. Ocean. 2013, 118, 3462-3472. [CrossRef]

28. Yang, G. Historical change and future trends of storm surge disaster in China's coastal area. J. Nat. Disasters 2000, 3, 23-30.

29. Wang, X.; Qian, C.; Wang, W.; Yan, T. An elliptical wind field model of typhoons. J. Ocean Univ. China 2004, 3, 33-39. [CrossRef]

30. Feng, J.; Lu, X.; Yu, H.; Zhang, W.; Ying, M.; Fan, Y.; Zhu, Y.; Chen, D. An Overview of the China Meteorological Administration Tropical Cyclone Database. JAtOT 2014, 31, 287-301.

31. Lu, X.; Yu, H.; Ying, M.; Zhao, B.; Zhang, S.; Lin, L.; Bai, L.; Wan, R. Western North Pacific Tropical Cyclone Database Created by the China Meteorological Administration. AdAtS 2021, 38, 690-699. [CrossRef]

32. CMA Tropical Cyclone Data Center. Available online: https:/ /tcdata.typhoon.org.cn/ (accessed on 10 November 2021).

33. Li, J.; Hou, Y.; Mo, D.; Liu, Q.; Zhang, Y. Influence of Tropical Cyclone Intensity and Size on Storm Surge in the Northern East China Sea. Remote Sens. 2019, 11, 3033. [CrossRef]

34. Weisberg, R.H.; Zheng, L.Y. Hurricane storm surge simulations for Tampa Bay. Estuar. Coasts 2006, 29, 899-913. [CrossRef]

35. Zhong, L.; Li, M.; Zhang, D.-L. How do uncertainties in hurricane model forecasts affect storm surge predictions in a semi-enclosed bay? Estuar. Coast. Shelf Sci. 2010, 90, 61-72. [CrossRef]

36. Booij, N.; Ris, R.C.; Holthuijsen, L.H. A third-generation wave model for coastal regions: 1. Model description and validation. J. Geophys. Res. Ocean. 1999, 104, 7649-7666. [CrossRef]

37. Wood, D.J.; Muttray, M.; Oumeraci, H. The SWAN model used to study wave evolution in a flume. Ocean. Eng. 2001, $28,805-823$. [CrossRef]

38. Feng, X.; Yin, B.; Yang, D. Development of an unstructured-grid wave-current coupled model and its application. Ocean. Model. 2016, 104, 213-225. [CrossRef]

39. De-zhou, Y.; Jin, W.; Bao-shu, Y.; Yan-qing, X.; Ri-na, S. Application of the SWAN wave model to Bohai Sea: Improvement of Phillips linear growth term. Adv. Water Sci. 2005, 16, 710-714.

40. Ris, R.C.; Holthuijsen, L.H.; Booij, N. A third-generation wave model for coastal regions: 2. Verification. J. Geophys. Res. Ocean. 1999, 104, 7667-7681. [CrossRef]

41. Jin, K.R.; Ji, Z.G. Calibration and verification of a spectral wind-wave model for Lake Okeechobee. Ocean. Eng. 2001, 28, 571-584. [CrossRef]

42. Padilla-Hernandez, R.; Monbaliu, J. Energy balance of wind waves as a function of the bottom friction formulation. Coast. Eng. 2001, 43, 131-148. [CrossRef]

43. Rogers, W.E.; Hwang, P.A.; Wang, D.W. Investigation of wave growth and decay in the SWAN model: Three regional-scale applications. J. Phys. Oceanogr. 2003, 33, 366-389. [CrossRef]

44. Alari, V.; Raudsepp, U.; Kõuts, T. Wind wave measurements and modelling in Küdema Bay, Estonian Archipelago Sea. J. Mar. Syst. 2008, 74, S30-S40. [CrossRef]

45. Westerink, J.; Luettich, J.R.; Baptista, A.; Scheffner, N.; Farrar, P. Tide and Storm Surge Predictions Using Finite Element Model. J. Hydraul. Eng. 1992, 118, 1373-1390. [CrossRef]

46. Luettich, J.R.; Westerink, J.; Scheffner, N. ADCIRC: An Advanced Three-Dimensional Circulation Model for Shelves, Coasts, and Estuaries. Report 1. Theory and Methodology of ADCIRC-2DDI and ADCIRC-3DL; DRP-92-6; US Army Corps of Engineers: Washington, DC, USA, 1992; p. 143. 
47. Westerink, J.; Luettich, J.R.; Blain, C.; Scheffner, N. ADCIRC: An Advanced Three-Dimensional Circulation Model for Shelves, Coasts, and Estuaries. Report 2. User's Manual for ADCIRC-2DDI; DRP-92-6; US Army Corps of Engineers: Washington, DC, USA, 1994; p. 168.

48. Ebersole, B.A.; Westerink, J.J.; Bunya, S.; Dietrich, J.C.; Cialone, M.A. Development of storm surge which led to flooding in St. Bernard Polder during Hurricane Katrina. Ocean. Eng. 2010, 37, 91-103. [CrossRef]

49. Blain, C.A.; Westerink, J.J.; Luettich Jr, R.A. Grid convergence studies for the prediction of hurricane storm surge. Int. J. Numer. Methods Fluids 1998, 26, 369-401. [CrossRef]

50. Yong-hua, C.; Qing-he, Z.; Shu-wang, Y.; Ze-zhou, J.; Hua, Y. Two Dimensional Current Field Analysis of Huanghua Port. China Harb. Eng. 2005, 136, 1-4.

51. Xin-gru, F.; Bao-shu, Y.; De-zhou, Y. Refined simulation and establishment of a tide and tidal current forecasting system in the Bohai Sea and the Yellow Sea. Mar. Forecast. 2011, 28, 65-69.

52. Murty, P.L.N.; Rao, A.D.; Srinivas, K.S.; Rao, E.P.R.; Bhaskaran, P.K. Effect of Wave Radiation Stress in Storm Surge-Induced Inundation: A Case Study for the East Coast of India. PApGe 2019, 177, 2993-3012. [CrossRef]

53. Dietrich, J.C.; Zijlema, M.; Westerink, J.J.; Holthuijsen, L.H.; Dawson, C.; Luettich, R.A.; Jensen, R.E.; Smith, J.M.; Stelling, G.S.; Stone, G.W. Modeling hurricane waves and storm surge using integrally-coupled, scalable computations. Coast. Eng. 2011, 58, 45-65. [CrossRef]

54. Dietrich, J.C.; Tanaka, S.; Westerink, J.J.; Dawson, C.N.; Luettich, R.A.; Zijlema, M.; Holthuijsen, L.H.; Smith, J.M.; Westerink, L.G.; Westerink, H.J. Performance of the Unstructured-Mesh, SWAN+ADCIRC Model in Computing Hurricane Waves and Surge. JSCom 2011, 52, 468-497. [CrossRef]

55. Deb, M.; Ferreira, C.M. Simulation of cyclone-induced storm surges in the low-lying delta of Bangladesh using coupled hydrodynamic and wave model ( SWAN+ADCIRC). J. Flood Risk Manag. 2016, 11, S750-S765. [CrossRef]

56. Yin, C.; Huang, H.; Wang, D.; Liu, Y.; Guo, Z. The Characteristics of Storm Wave Behavior and Its Effect on Cage Culture Using the ADCIRC+SWAN Model in Houshui Bay, China. J. Ocean Univ. China 2020, 19, 307-319. [CrossRef]

57. Cavaleri, L.; Bertotti, L. The improvement of modelled wind and wave fields with increasing resolution. Ocean. Eng. 2006, 33, 553-565. [CrossRef]

58. Moeini, M.H.; Etemad-Shahidi, A.; Chegini, V. Wave modeling and extreme value analysis off the northern coast of the Persian Gulf. Appl. Ocean. Res. 2010, 32, 209-218. [CrossRef]

59. Signell, R.P.; Carniel, S.; Cavaleri, L.; Chiggiato, J.; Doyle, J.D.; Pullen, J.; Sclavo, M. Assessment of wind quality for oceanographic modelling in semi-enclosed basins. J. Mar. Syst. 2005, 53, 217-233. [CrossRef]

60. Xiangui, M. Preliminarily assessment of ERA5 reanalysis data. J. Mar. Meteorol. 2018, 38, 91-99.

61. Ai-lian, L. Applicability of the ERA5 reanalysis data to China adjacent Sea under typhoon condition. Mar. Sci. 2021, 45, 71-80.

62. Du, M.; Hou, Y.; Guo, Y.; Wang, K. Numerical Simulation and Risk Analysis of Coastal Inundation in Land Reclamation Areas: A Case Study of the Pearl River Estuary. J. Ocean Univ. China 2020, 19, 1221-1234. [CrossRef]

63. Wu, G.; Shi, F.; Kirby, J.T.; Liang, B.; Shi, J. Modeling wave effects on storm surge and coastal inundation. Coast. Eng. 2018, 140, 371-382. [CrossRef]

64. Holland, G. A revised hurricane pressure-wind model. MWRv 2008, 136, 3432-3445. [CrossRef]

65. Landsea, C. A Climatology of Intense (or Major) Atlantic Hurricanes. MWRv 1993, 121, 1703-1713. [CrossRef]

66. Harper, B. Tropical Cyclone Parameter Estimation in the Australian Region: Wind-Pressure Relationships and Related Issues for Engineering Planning and Design-A Discussion Paper; J0106-PR003E; Systems Engineering Australia Pty Ltd.: Newstead, QLD, Australia, 2002; p. 93.

67. Knaff, J.A.; Zehr, R.M. Reexamination of tropical cyclone wind-pressure relationships. Weather Forecast. 2007, 22, 71-88. [CrossRef]

68. Carrasco, C.A.; Landsea, C.W.; Lin, Y.-L. The Influence of Tropical Cyclone Size on Its Intensification. Weather Forecast. 2014, 29, 582-590. [CrossRef]

69. Irish, J.L.; Resio, D.T.; Ratcliff, J.J. The Influence of Storm Size on Hurricane Surge. J. Phys. Oceanogr. 2008, 38, 2003-2013. [CrossRef]

70. Condon, A.J.; Sheng, Y.P. Optimal storm generation for evaluation of the storm surge inundation threat. Ocean. Eng. 2012, 43, 13-22. [CrossRef]

71. Rego, J.L.; Li, C. On the importance of the forward speed of hurricanes in storm surge forecasting: A numerical study. Geophys. Res. Lett. 2009, 36, L07609. [CrossRef]

72. Clarke, A.J.; Battisti, D.S. The effect of continental shelves on tides. Deep. Sea Res. Part A Oceanogr. Res. Pap. 1981, 28, 665-682. [CrossRef]

73. Wenxin, S.; Wensheng, J.; Lei, L. Numerical Model of Offshore Environment Fluid Dynamics; Science Press: Beijing, China, 2004; pp. 11-13. 